\title{
Food Waste to Energy: An Overview of Sustainable Approaches for Food Waste Management and Nutrient Recycling
}

\author{
Kunwar Paritosh, ${ }^{1}$ Sandeep K. Kushwaha, ${ }^{2}$ Monika Yadav, ${ }^{1}$ Nidhi Pareek, ${ }^{3}$ \\ Aakash Chawade, ${ }^{2}$ and Vivekanand Vivekanand ${ }^{1}$ \\ ${ }^{1}$ Centre for Energy and Environment, Malaviya National Institute of Technology, Jaipur, Rajasthan 302017, India \\ ${ }^{2}$ Department of Plant Breeding, Swedish University of Agricultural Sciences, P.O. Box 101, 23053 Alnarp, Sweden \\ ${ }^{3}$ Department of Microbiology, School of Life Sciences, Central University of Rajasthan Bandarsindri, Kishangarh, \\ Ajmer, Rajasthan 305801, India
}

Correspondence should be addressed to Vivekanand Vivekanand; vivekanand.cee@mnit.ac.in

Received 14 November 2016; Revised 29 December 2016; Accepted 12 January 2017; Published 14 February 2017

Academic Editor: José L. Campos

Copyright (C) 2017 Kunwar Paritosh et al. This is an open access article distributed under the Creative Commons Attribution License, which permits unrestricted use, distribution, and reproduction in any medium, provided the original work is properly cited.

Food wastage and its accumulation are becoming a critical problem around the globe due to continuous increase of the world population. The exponential growth in food waste is imposing serious threats to our society like environmental pollution, health risk, and scarcity of dumping land. There is an urgent need to take appropriate measures to reduce food waste burden by adopting standard management practices. Currently, various kinds of approaches are investigated in waste food processing and management for societal benefits and applications. Anaerobic digestion approach has appeared as one of the most ecofriendly and promising solutions for food wastes management, energy, and nutrient production, which can contribute to world's ever-increasing energy requirements. Here, we have briefly described and explored the different aspects of anaerobic biodegrading approaches for food waste, effects of cosubstrates, effect of environmental factors, contribution of microbial population, and available computational resources for food waste management researches.

\section{Introduction}

Food Waste. Food waste (FW) (both precooked and leftover) is a biodegradable waste discharged from various sources including food processing industries, households, and hospitality sector. According to FAO, nearly 1.3 billion tonnes of food including fresh vegetables, fruits, meat, bakery, and dairy products are lost along the food supply chain [1]. The amount of FW has been projected to increase in the next 25 years due to economic and population growth, mainly in the Asian countries. It has been reported that the annual amount of urban FW in Asian countries could rise from 278 to 416 million tonnes from 2005 to 2025 [2]. Approximately 1.4 billion hectares of fertile land (28\% of the world's agricultural area) is used annually to produce food that is lost or wasted. Apart from food and land resource wastage, the carbon footprint of food waste is estimated to contribute to the greenhouse gas (GHG) emissions by accumulating approximately
3.3 billion tonnes of $\mathrm{CO}_{2}$ into the atmosphere per year. Conventionally, this food waste, which is a component of municipal solid waste, is incinerated [3-7] or dumped in open area which may cause severe health and environmental issues. Incineration of food waste consisting high moisture content results in the release of dioxins [8] which may further lead to several environmental problems. Also, incineration reduces the economic value of the substrate as it hinders the recovery of nutrients and valuable chemical compounds from the incinerated substrate. Therefore, appropriate methods are required for the management of food waste [9]. Anaerobic digestion can be an alluring option to strengthen world's energy security by employing food waste to generate biogas while addressing waste management and nutrient recycling. The quantity of wasted food around the globe and its bioenergy potential via anaerobic digestion were reported earlier $[10,11]$ and are summarized in this work (Figures 1 and 2). 

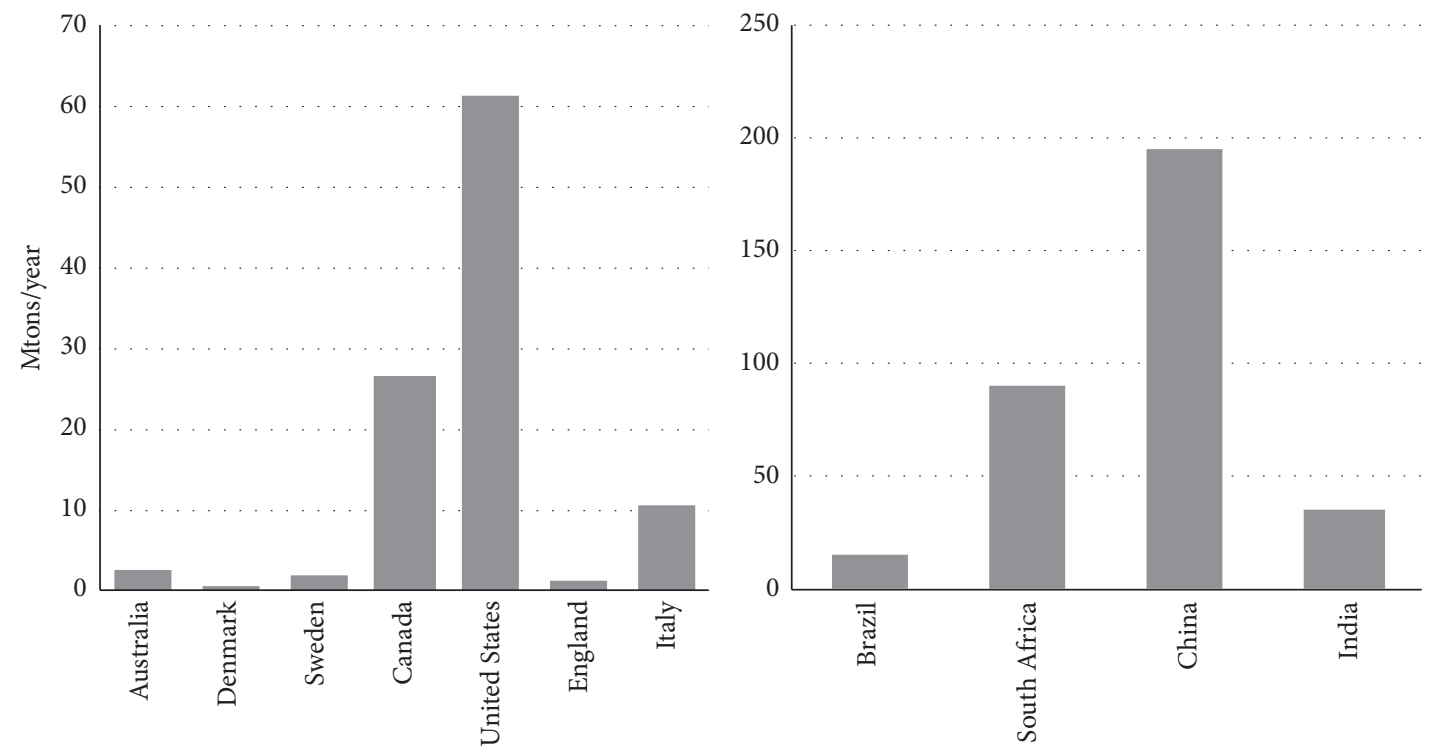

(a)
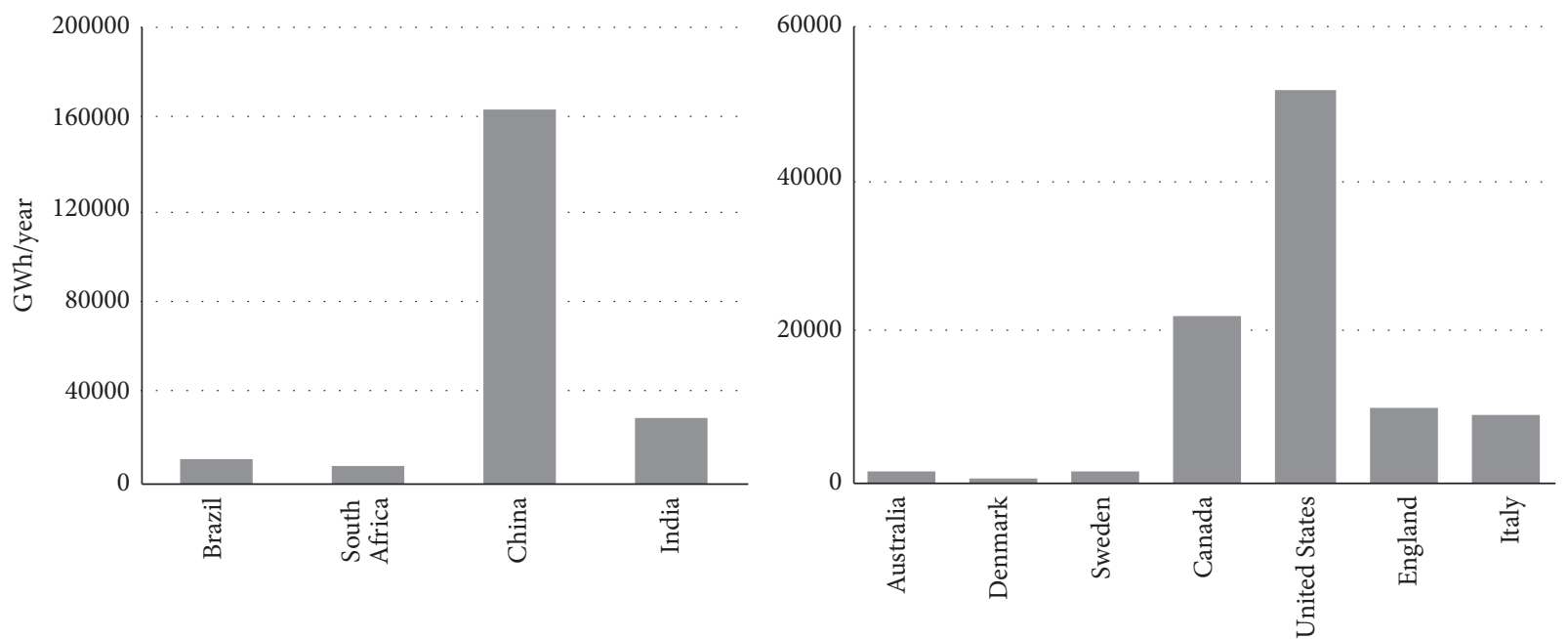

(b)
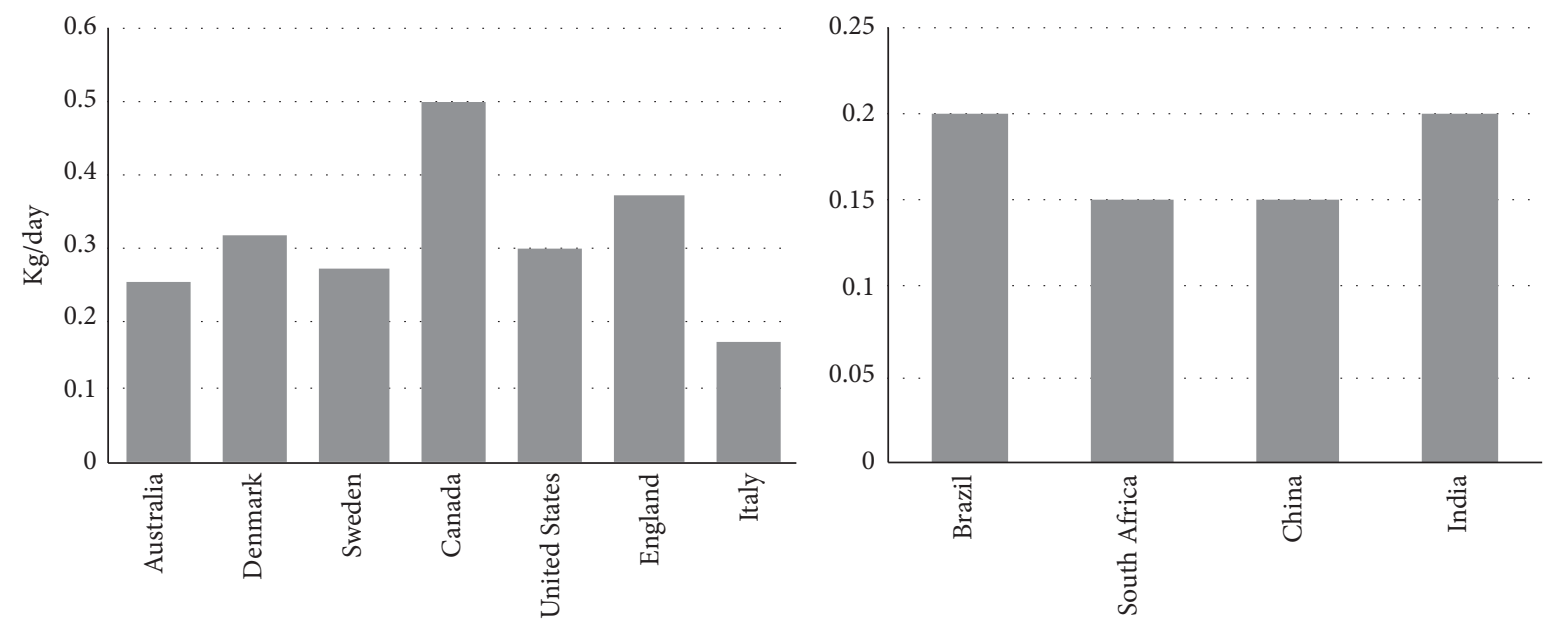

(c)

FIGURE 1: (a) Worldwide generation of food waste in developed and developing countries. (b) Worldwide bioenergy potential from FW in developed and developing countries. (c) Per capita food waste generation in developed and developing countries. 


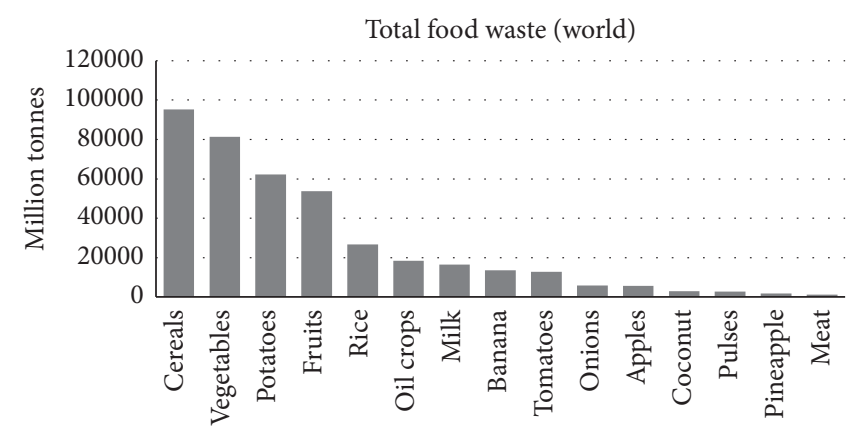

(a)

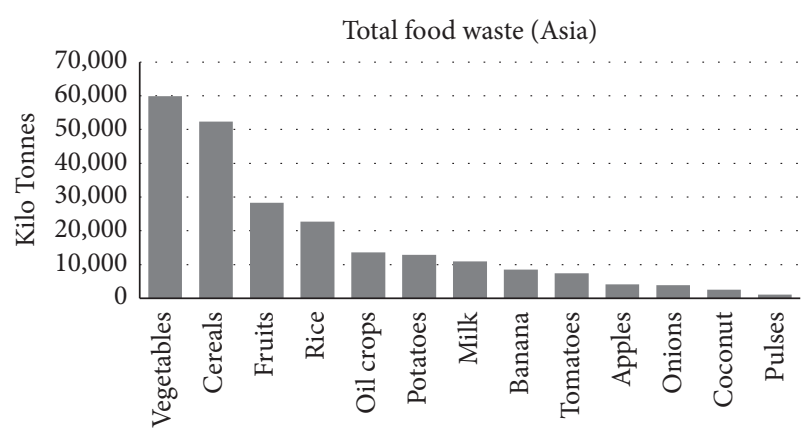

(b)

Figure 2: Typical wasted foods in world and in Asia.

Food waste mainly consists of carbohydrates, proteins, lipids, and traces of inorganic compounds. The composition varies in accordance with the type of food waste and its constituents. Food waste consisting of rice and vegetables is abundant in carbohydrates while food waste consisting of meat and eggs has high quantity of proteins and lipids. Table 1 summarizes the composition of food waste studied in different parts of the globe.

\section{Anaerobic Digestion}

Generation of methane via anaerobic process is an appropriate solution for food waste management. The process has lesser cost and low residual waste production and utilization of food waste as renewable source of energy [12, 13]. Table 2 summarizes the studies pertaining to anaerobic digestion of various kinds of FWs.

Anaerobic digestion consists broadly of three phases, namely, enzymatic hydrolysis, acid formation, and gas production; Figure 3 depicts the digestion process.

2.1. Enzymatic Hydrolysis. In the first phase, large polymer molecules that cannot be transported to cell membranes by microorganisms are broken down by hydrolases secreted by facultative or obligate anaerobic hydrolytic bacteria. Hydrolysis breaks down the polymers into oligomer or monomeric units. Polysaccharides are broken down into oligosaccharides and monosaccharides; for example, (1) represents production of glucose molecules by starch hydrolysis. Proteins are broken down into peptides and amino acids and lipids are converted into glycerol and fatty acid.

$$
n \mathrm{C}_{6} \mathrm{H}_{10} \mathrm{O}_{5}+n \mathrm{H}_{2} \mathrm{O} \longrightarrow n \mathrm{C}_{6} \mathrm{H}_{12} \mathrm{O}_{6}
$$

Mittal [42] reported that, in the anaerobic conditions, the hydrolysis rate is relatively slower than the rate of acid formation and depends on the nature of substrate, bacterial concentration, $\mathrm{pH}$, and the temperature of the bioreactor. Other parameters such as size of the substrate particles, $\mathrm{pH}$, production of enzymes, and adsorption of enzymes on the substrate particles also affect the hydrolysis rate. Bryant [43] reported that Streptococcus and Enterobacter are genera of anaerobes that are responsible for hydrolysis.
2.2. Acidogenesis Phase. In the second phase, acidogenesis takes place in which hydrolytic products are fermented to volatile fatty acids such as acetate, propionate, butyrate, valerate, and isobutyrate along with carbon dioxide, hydrogen, and ammonia. During acidification, facultative anaerobic bacteria utilize oxygen and carbon creating an anaerobic condition for methanogenesis. The monomers obtained in phase one become substrates for the microbes in phase two where the substrates are converted into organic acids by a group of bacteria.

Acetate, hydrogen, and carbon dioxide can be utilized directly for methane production. However, propionate, butyrate, valerate, and isobutyrate are introduced for further degradation by syntrophic acetogenic bacteria to form acetate and hydrogen [42-44].

2.3. Acetogenesis. Acetogenic bacteria belonging to genera Syntrophomonas and Syntrophobacter [44] convert the acid phase products into acetates (2) and hydrogen. Few acetate molecules are also generated by reduction of carbon dioxide using hydrogen as an electron source. Acetates will further be utilized by methanogens in subsequent steps. However, hydrogen released in the process exerts inhibitory effect on microorganisms. Therefore, in anaerobic digesters, acetogenic bacteria live in syntrophic relationship with hydrogenotrophic methanogens that remove the hydrogen by utilizing it for methane formation. Also, acetogenesis is the phase, which depicts the efficiency of the biogas production because $70 \%$ of methane arises when acetate reduces. Simultaneously, $11 \%$ hydrogen is also formed during the process [44].

$$
n \mathrm{C}_{6} \mathrm{H}_{12} \mathrm{O}_{6} \longrightarrow 3 n \mathrm{CH}_{3} \mathrm{COOH}
$$

2.4. Methanogenesis. In the last phase, methanogenesis takes place which is carried out by methanogens, belonging to Archaea. Methane can be produced either by fermentation of acetic acid or by reducing carbon dioxide. Therefore, the products of previous phase, that is, acetic acid, hydrogen, and carbon dioxide, act as a precursor for methane formation. Only $30 \%$ of methane produced in this process comes from 
TABLE 1: Composition of FW reported in various literatures.

\begin{tabular}{lccccccccc}
\hline Moisture & Total solid & Volatile solid & Total sugar & Starch & Cellulose & Lipids & Protein & Ash & References \\
\hline 75.9 & 24.1 & NR & 42.3 & 29.3 & NR & NR & 3.9 & 1.3 & {$[14]$} \\
80.3 & 19.7 & 95.4 & 59.8 & NR & 1.6 & 15.7 & 21.8 & 1.9 & {$[15]$} \\
82.8 & 17.2 & 89.1 & 62.7 & 46.1 & 2.3 & 18.1 & 15.6 & NR & {$[16]$} \\
75.2 & 24.8 & NR & 50.2 & 46.1 & NR & 18.1 & 15.6 & 2.3 & {$[16]$} \\
85.7 & 14.3 & 98.2 & 42.3 & 28.3 & NR & NR & 17.8 & NR & {$[17]$} \\
82.8 & 17.2 & 85.0 & 62.7 & 46.1 & 2.3 & 18.1 & 15.6 & NR & {$[18]$} \\
61.3 & 38.7 & NR & 69.0 & NR & NR & 6.4 & 4.4 & 1.2 & {$[19]$} \\
81.7 & 18.3 & 87.5 & 35.5 & NR & NR & 24.1 & 14.4 & NR & {$[20]$} \\
81.5 & 18.5 & 94.1 & 55.0 & 24.0 & 16.9 & 14.0 & 16.9 & 5.9 & {$[21]$} \\
81.9 & 14.3 & 98.2 & 48.3 & 42.3 & NR & NR & 17.8 & NR & {$[22]$} \\
\hline
\end{tabular}

TABLE 2: Anaerobic digestion processes of food waste for methane production.

\begin{tabular}{|c|c|c|c|c|c|c|c|}
\hline Waste & Inoculum & Vessel type & Duration $(\mathrm{d})$ & $\operatorname{HRT}(d)$ & $\begin{array}{l}\mathrm{CH}_{4} \text { yield } \\
(\mathrm{ml} / \mathrm{g} \mathrm{VS})\end{array}$ & $\% \mathrm{CH}_{4}$ & References \\
\hline FW & Cow manure & $\begin{array}{l}\text { Bioreactor with } .5 \mathrm{~L} \text { working } \\
\text { volume }\end{array}$ & 29 & 1 & 530 & 70 & [23] \\
\hline FW & Anaerobic SS & Pilot scale 5 tons/d & 90 & NR & 440 & 70 & [24] \\
\hline FW & Anaerobic SS & $\begin{array}{l}\text { Bioreactor with } 12 \mathrm{~L} \text { working } \\
\text { volume }\end{array}$ & 60 & 20 & NR & 68.8 & {$[25]$} \\
\hline FW & SS & $\begin{array}{l}\text { Bioreactor with } 4.5 \mathrm{~L} \text { working } \\
\text { volume }\end{array}$ & 200 & $1-27$ & 520 & 90 & [26] \\
\hline FW & NR & $900 \mathrm{~m}^{3}$ tank volume & 426 & 80 & 399 & 62 & {$[27]$} \\
\hline FW & Anaerobic SS & CSTR with $3 \mathrm{~L}$ working volume & 225 & 16 & 455 & NR & {$[28]$} \\
\hline FW & NR & $\begin{array}{c}\text { Digester with } 800 \mathrm{ml} \text { working } \\
\text { volume }\end{array}$ & 30 & Batch & 410 & 66 & {$[29]$} \\
\hline FW & Anaerobic SS & Batch & 28 & $10-28$ & 440 & 73 & {$[30]$} \\
\hline FW & SS & CSTR with $10 \mathrm{~L}$ working volume & 150 & 5 & 464 & 80 & {$[31]$} \\
\hline FW & $\begin{array}{l}\text { Landfill soil and cow } \\
\text { manure }\end{array}$ & Batch $5 \mathrm{~L}$ & 60 & $20-60$ & 220 & NR & {$[32]$} \\
\hline
\end{tabular}

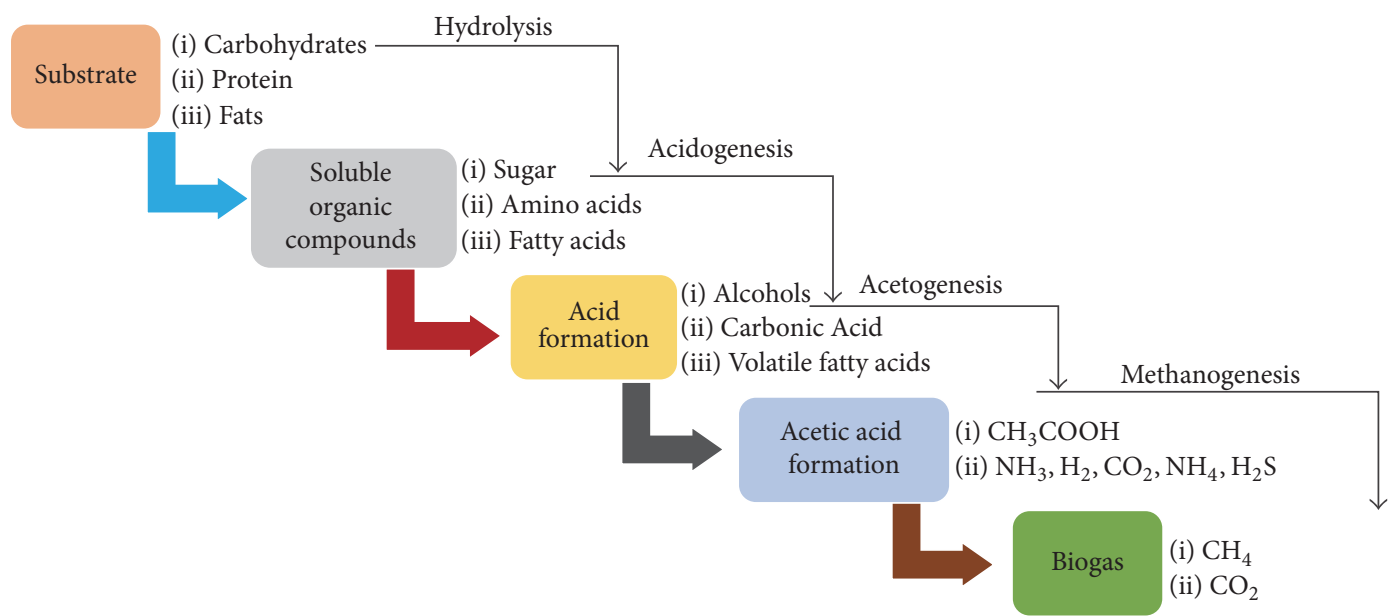

Figure 3: Anaerobic digestion phases. 
TABLE 3: Microorganism cooperation in organic matter degradation [33, 34].

\begin{tabular}{|c|c|c|c|}
\hline Reaction Type & Microorganism & Active Genera & Product \\
\hline Fermentation & Hydrolytic bacteria & $\begin{array}{c}\text { Bacteroides, Lactobacillus, } \\
\text { Propionibacterium, Sphingomonas, } \\
\text { Sporobacterium, Megasphaera, } \\
\text { Bifidobacterium }\end{array}$ & $\begin{array}{l}\text { Simple sugars, peptides, } \\
\text { fatty acids }\end{array}$ \\
\hline Acidogenesis & Syntropic bacteria & Ruminococcus, Paenibacillus, Clostridium & Volatile fatty acids \\
\hline Acetogenesis & Acetogenic bacteria & $\begin{array}{c}\text { Desulfovibrio, Aminobacterium, } \\
\text { Acidaminococcus }\end{array}$ & $\mathrm{CH}_{3} \mathrm{COOH}$ \\
\hline Methanogenesis & Methanogens (Archaea) & $\begin{array}{l}\text { Methanosaeta, Methanolobus, } \\
\text { Methanococcoides, Methanohalophilus, } \\
\text { Methanosalsus, Methanohalobium, } \\
\text { Halomethanococcus, Methanolacinia, } \\
\text { Methanogenium, Methanoculleus }\end{array}$ & $\mathrm{CH}_{4}$ \\
\hline
\end{tabular}

carbon dioxide reduction carried out by methanogens [45, 46].

$$
\mathrm{CH}_{3} \mathrm{COOH} \longrightarrow \mathrm{CH}_{4}+\mathrm{CO}_{2}
$$

Methane can be generated in two ways by two types of methanogens: (a) acetoclastic methanogens that produce methane from acetic acid and (b) hydrogenotrophic methanogens that utilize hydrogen to reduce carbon dioxide.

$$
\mathrm{CO}_{2}+4 \mathrm{H}_{2} \rightarrow \mathrm{CH}_{4}+3 \mathrm{H}_{2} \mathrm{O}
$$

Table 3 summarizes genera active in anaerobic digestion and the microorganism cooperation in organic matter degradation.

\section{Food Waste as a Substrate}

Degradability of food waste used as substrate mainly depends upon its chemical composition. It is quite challenging to know the exact percentage of different components of the complex substrate because of its heterogeneous nature. Various researchers have investigated the potential of food waste as a substrate for biomethanation. Viturtia et al. [47] inspected two stages of anaerobic digestion of fruit and vegetable wastes and achieved 95.1\% volatile solids (VS) conversion with a methane yield of $530 \mathrm{~mL} / \mathrm{g}$ VS. In a study performed by Lee et al. [23], FW was converted into methane using a 5-L continuous digester, resulting in 70\% VS conversion with a methane yield of $440 \mathrm{~mL} / \mathrm{g}$ VS. Gunaseelan [24] used around 54 different types of food and reported methane yield ranged from 180 to $732 \mathrm{~mL} / \mathrm{g}$ VS depending on the origin of wastes. Cho et al. [48] reported $472 \mathrm{ml} / \mathrm{g}$ VS methane yield with $86 \%$ anaerobic biodegradability of the Korean food waste. Yong et al. [49] have reported $0.392 \mathrm{~m}^{3} \mathrm{CH}_{4} / \mathrm{kg}-\mathrm{VS}$ when canteen food waste mixed with straw in the ratio of $5: 1$. Food waste as a substrate has potential to provide high biogas yield in comparison to cow manure, whey, pig manure, corn silage, and so forth [50].

\section{Key Parameters Affecting Biomethanation}

For anaerobes to work with high metabolic activity, it is imperative to have controlled environmental conditions. The methanogenic bacteria are very sensitive towards unfavorable survival conditions. Therefore, it is vital to maintain optimal condition to flourish the process of methanation. Biomethanation process primarily depends upon seeding, temperature, $\mathrm{pH}$, carbon-nitrogen $(\mathrm{C} / \mathrm{N})$ ratio, volatile fatty acids (VFAs), organic loading rate (OLR), alkalinity, total volatile solids (VS), and hydraulic retention time (HRT) and nutrients concentration. It was also reported that the concentrations of water soluble material such as sugar, amino acids, protein, and minerals decrease and water nonsoluble materials such as lignin, cellulose, and hemicellulose increase in content [51].

4.1. Seeding. Seeding may speed up the stabilization of the digestion process. The most commonly used materials for inoculation are digested sludge from sewage plant, landfill soil, and cow dung slurry.

It was reported that the use of goat rumen fluid [52] as inoculum at the rate of $8 \%(\mathrm{v} / \mathrm{v})$ is very efficient for biogas production.

4.2. Temperature. Methanogenesis has been reported from $2^{\circ} \mathrm{C}$ in marine sediments to over $100^{\circ} \mathrm{C}$ in geothermal areas [53]. Methanogens thrive best at around $35^{\circ} \mathrm{C}$ (mesophilic) and $55^{\circ} \mathrm{C}$ (thermophilic), respectively. Environmental temperature is also a huge concern for anaerobic microbial culture as change of acetic acid to methane depends mostly upon temperature. It has been reported that the optimum range of temperature is $35-40^{\circ} \mathrm{C}$ for mesophilic activity and $50-65^{\circ} \mathrm{C}$ for thermophilic activity $[54,55]$. Bouallagui et al. [56] have reported that, at $4 \%$ total solid, methane content was found to be $58 \%, 65 \%$, and $62 \%$ at temperatures $20^{\circ} \mathrm{C}$, $35^{\circ} \mathrm{C}$, and $55^{\circ} \mathrm{C}$, respectively. At $8 \%$ total solid, methane content was found to be $57 \%$ and $59 \%$ at $35^{\circ} \mathrm{C}$ and $55^{\circ} \mathrm{C}$, respectively. In a study reported by Kim et al. [57], methane content was found to be $65.6 \%, 66.2 \%, 67.4 \%$, and $58.9 \%$ at temperatures $40^{\circ} \mathrm{C}, 45^{\circ} \mathrm{C}, 50^{\circ} \mathrm{C}$, and $55^{\circ} \mathrm{C}$, respectively. In another experiment performed by Gou et al. [58] codigestion 
TABLE 4: C/N ratio for some materials.

\begin{tabular}{lcc}
\hline Material & $\% \mathrm{~N}$ & $\mathrm{C}: \mathrm{N}$ \\
\hline Animal urine & $15-20$ & 1 \\
Cotton stalks & 1.7 & 30 \\
Cow, buffalo manure & $1.4-3$ & $15-40$ \\
Oat straw, flax straw & $1-1.2$ & $50-60$ \\
Wheat and rice straw & $0.3-0.5$ & $120-150$ \\
Sawdust & $0.1-0.25$ & $200-500$ \\
\hline
\end{tabular}

of waste activated sludge with food waste was reported to have highest gas production rate at $55^{\circ} \mathrm{C}$ which was 1.6 and 1.3 times higher than the gas production at $35^{\circ} \mathrm{C}$ and $45^{\circ} \mathrm{C}$.

4.3. $p H$. The $\mathrm{pH}$ of bioreactor affects the microbial activity in anaerobic digestion and its efficiency. Wang et al. [59] reported that optimum $\mathrm{pH}$ range is $6.3-7.8$. Initially due to excess of carbon dioxide, $\mathrm{pH}$ drops to 6.2 and after 10 days it starts rising and stabilizes between 7 and 8 . Also, Lee et al. [60] indicated that optimum range of methanogenesis using food waste leachate was 6.5-8.2. The main reasons for $\mathrm{pH}$ variation are VFAs, bicarbonate concentration, and alkalinity of the system. Goel et al. [61] used $\mathrm{NaOH}$ and $\mathrm{NaHCO}_{3}$ for controlling $\mathrm{pH}$ in anaerobic digestion used for biomethanation from food waste.

4.4. Carbon/Nitrogen Ratio. Mittal [62] has reported that digestion of substrate will proceed more rapidly if the $\mathrm{C} / \mathrm{N}$ ratio would be 25-30:1. This leads to a conclusion that bacterial community use up carbon 25-30 times faster than nitrogen. If the ratio is not adequate, the nitrogen would get exhausted while there would be some carbon left which will cause bacteria to die. Excess of nitrogen would lead to ammonia formation which will inhibit the digestion process. Codigesting dairy manure, chicken manure, and wheat straw yielded maximum methane when $\mathrm{C} / \mathrm{N}$ ratio was 27.2 with stable $\mathrm{pH}$ [59]. In another study performed by Zeshan et al. [63], anaerobic digestion performed well at $\mathrm{C} / \mathrm{N}$ ratio of 27. An optimum amount of carbon content was having positive effect on avoiding excessive ammonia inhibition [64-66]. Table 4 [67] summarizes the $\mathrm{C} / \mathrm{N}$ ratio of a few selected feed stock.

4.5. Volatile Fatty Acids (VFAs). It has been reported that the production and accumulation of volatile fatty acid (VFAs) could show inhibitory and detrimental effects on anaerobic digestion process which could lead to slow production of biogas [68-70]. VFAs inhibition on the activity of methanogens is caused by a $\mathrm{pH}$ drop, which may lead to the activity loss of acid-sensitive enzymes [71]. Also, high levels of undissociated acids, which can penetrate cell membranes, may damage macromolecules [72]. The concentration of VFA in anaerobic digestion for the solid state of food wastes could rise up to $20 \mathrm{~g} / \mathrm{L}$, which is much higher than that in a wastewater anaerobic process [73]. In the optimum conditions required for metabolic activity, VFAs range in between $2000-3000 \mathrm{mg} / \mathrm{L}$ [74].
4.6. Organic Loading Rate (OLR). Organic loading rate simply refers to quantity of feed processed per unit volume of reactor per day. Taiganides [75] had reported that controlled digestion is attained when the loading rate is between $0.5 \mathrm{~kg}$ and $2 \mathrm{~kg}$ of total $\mathrm{VS} / \mathrm{m}^{3} / \mathrm{d}$. In an experiment conducted by Nagao et al. [76], the volumetric biogas production rate increased to approximately $2.7,4.2,5.8$, and $6.6 \mathrm{~L} / \mathrm{L} / \mathrm{d}$ as OLR increased to $3.7,5.5,7.4$, and $9.2 \mathrm{~kg}-\mathrm{VS} \mathrm{m}^{3} / \mathrm{d}$, respectively, and was maintained at the same. At the highest OLR (12.9 kg-VS $\mathrm{m}^{3} / \mathrm{d}$ ), the volumetric gas production rate decreased below the gas production rate at OLR of $7.4 \mathrm{~kg}-\mathrm{VS} \mathrm{m}^{3} / \mathrm{d}$. In a study performed for comparing autoclaved and untreated food waste [77], highest methane yield was obtained at organic loading rate of $3 \mathrm{~kg} \mathrm{VS} / \mathrm{m}^{3} \mathrm{~d}$ for untreated food waste and at $4 \mathrm{~kg} \mathrm{VS} / \mathrm{m}^{3} \mathrm{~d}$ for autoclaved food waste. The study was conducted at 2, 3, 4, and $6 \mathrm{~kg} \mathrm{VS} / \mathrm{m}^{3} \mathrm{~d}$. Agyeman and Tao [78] digested food waste with dairy manure anaerobically at different organic loading rates and reported that biogas production rate increased by $101-116 \%$ when OLR was increased from 1 to $2 \mathrm{~g} \mathrm{VS} / \mathrm{L} / \mathrm{d}$ and only by $25-38 \%$ when OLR was further increased from 2 to $3 \mathrm{~g} \mathrm{VS} / \mathrm{L} / \mathrm{d}$. Specific methane yield peaked at the OLR of $2 \mathrm{~g} \mathrm{VS} / \mathrm{L} / \mathrm{d}$ in the digesters with fine and medium food waste. Also, codigestion of food waste with activated sludge was performed in both mesophilic and thermophilic anaerobic systems at different OLR. The thermophilic system exhibited the best load bearing capacity at extremely high OLR of $7 \mathrm{~g} \mathrm{VS} / \mathrm{L} / \mathrm{d}$, while the mesophilic system showed the best process stability at low OLRs (<5 g VS/L/d) [79].

For a given size of biogas plant, there would be an optimum loading rate beyond which further loading will not be fruitful as it may lead to accumulation of excess VFAs and results in a collapsed reactor [80].

4.7. Ammonia. Biodegradation of protein or other nitrogenrich substrate produces ammonia and exists in the form of ammonium ion $\left(\mathrm{NH}_{4}{ }^{+}\right)$and $\mathrm{NH}_{3}[81,82]$. It could be beneficial for the growth of microbes or sometime have detrimental effect on them [82, 83]. Ammonia plays a vital role in $\mathrm{C} / \mathrm{N}$ ratio and could affect the performance of digestion process [59]. The reaction between ammonia and VFAs have been reported by Zhang et al. [84] and are as follows:

$$
\begin{aligned}
& \mathrm{C}_{x} \mathrm{H}_{y} \mathrm{COOH} \rightleftharpoons \mathrm{C}_{x} \mathrm{H}_{y} \mathrm{COO}^{-}+\mathrm{H}^{+} \\
& \mathrm{NH}_{3} \cdot \mathrm{H}_{2} \mathrm{O} \rightleftharpoons \mathrm{NH}_{4}^{+}+\mathrm{OH}^{-} \\
& \mathrm{C}_{x} \mathrm{H}_{y} \mathrm{COOH}+\mathrm{NH}_{3} \times \mathrm{H}_{2} \mathrm{O} \\
& \longrightarrow \mathrm{C}_{x} \mathrm{H}_{y} \mathrm{COO}^{-}+\mathrm{NH}_{4}^{+}+\mathrm{H}_{2} \mathrm{O},
\end{aligned}
$$

where $\mathrm{C}_{x} \mathrm{H}_{y} \mathrm{COOH}$ represents VFAs.

4.8. Nutrient. Microbes use carbon to fulfil energy requirement and nitrogen for building cell wall structure. In addition, microbes also need small quantity of micro nutrient [85] such as calcium, sodium, potassium, magnesium, and chlorine. Also, for enzyme synthesis and for maintaining 
enzyme activity, heavy metal ions such as $\mathrm{Cr}, \mathrm{Co}, \mathrm{Cu}$, $\mathrm{Zn}$, and $\mathrm{Ni}$ are required in biomethanation [86-88]. Effect of concentration of sodium, potassium, and calcium was observed during anaerobic digestion activity. No inhibition was observed when concentration of calcium was increased up to $7000 \mathrm{mg} / \mathrm{L}$ [89]; however optimum concentration was reported 150-300 mg/L [90]. Concentration of heavy metals could have inhibitory effects on methanogenic activity and inhibition degrees depend upon many factors, such as the total metal concentration, chemical forms of the metals, $\mathrm{pH}$, and redox potential $[91,92]$.

\section{Biochemical Methane Potential (BMP)}

Biochemical methane potential is an important assay for elucidation of anaerobic digestion. There is an increased adaptation of BMP assay in recent studies.

In an experiment performed for mixed food waste like boiled rice, cabbage, and cooked meat which were digested with cellulase as control has manifested greater rate of production of methane which is about $472 \mathrm{ml} / \mathrm{g}$ VS with total reduction in VS up to $86 \%$ [48].

In another study performed on canteen waste mixed with straw in different ratios, BMP for food waste and straw was 0.26 and $0.16 \mathrm{~m}^{3} \mathrm{CH}_{4} / \mathrm{kg}$-VS, respectively, which shows that food waste is easily biodegradable waste while the straw was difficult to degrade anaerobically which may be due to presence of lignin [49].

Digesting food and vegetables anaerobically yielded methane with a minimum amount of $0.3 \mathrm{~L} / \mathrm{g}$ VS in every sample which also incorporate as commercial value for anaerobic digestion [93]. In an experiment conducted by Elbeshbishy et al. [94], preincubated seed sludge has been used along with running seed sludge for BMP test of food waste along with primary sludge. The maximum methane production rates using nonincubated inoculum were higher $(114 \mathrm{~mL}$ $\mathrm{CH}_{4}{ }^{-\mathrm{g}} \mathrm{TCOD}_{\text {sub }}$ ) than those using preincubated inoculum at all substrate-to-inoculum ratios. Lisboa and Lansing [95] codigested four food waste substrates (meatball, chicken, cranberry, and ice cream processing wastes) for 69 days with flushed dairy manure and have reported an increase in methane production. Their findings suggested that addition of even small quantity of food waste to dairy manure has significantly enhanced the BMP levels. It was observed that the extent of increase in BMP following the addition of food waste had wide range starting from 67 to $2940 \%$ for ice cream and chicken processing waste, respectively.

Biogas potential of the dry fraction from pretreatment of food waste from households has been evaluated by Murto et al. [96]. A higher methane yield $\left(152 \pm 22 \mathrm{~m}^{3} /\right.$ ton $)$ was obtained from digestion of the dry fraction alone. Dry fraction mixed with structural material produced lower levels of biogas $\left(112 \pm 21 \mathrm{~m}^{3} /\right.$ ton $)$ compared to digestion of dry fraction alone.

Autoclaved and untreated food waste BMP assay was performed by Tampio et al. [77]. Food waste was autoclaved at $1600^{\circ} \mathrm{C}, 6.2$ bar. It has been reported that methane yield at all the loading rates $\left(2,3,4\right.$, and $\left.6 \mathrm{~kg}-\mathrm{VS} / \mathrm{m}^{3} / \mathrm{d}\right)$ was $5-10 \%$ higher for untreated food waste which was $0.483 \mathrm{~m}^{3} \mathrm{CH}_{4} / \mathrm{kg}$ VS as compared to $0.439 \mathrm{~m}^{3} \mathrm{CH}_{4} / \mathrm{kg}$ VS obtained from autoclaved food waste.

\section{Pretreatment Methods for Food Waste}

Anaerobic digestion is now widely embraced to manage solid waste and energy recovery. However, the recalcitrance imposed by the compositional and structural features of food waste, that is, degree of polymerisation, crystallinity, lignin and pectin content, accessible surface area, and so forth, results in limiting the hydrolysis step of anaerobic digestion, such as food waste containing uncooked vegetables that consist of raw starch that has high degree of crystallinity which hinders its hydrolytic degradation. Therefore, a pretreatment step prior to anaerobic digestion is required to increase the degradability of food waste by increasing the surface area and reducing the degree of polymerisation and crystallinity. Pretreatment technologies like mechanical, thermal, chemical, and biological ones may be applied prior to anaerobic digestion to reduce the crystallinity and enhance the production of methane using wasted food. Research is earlier carried out to investigate the effect of different pretreatment methods on anaerobic digestion of food waste. Microwave pretreatment of food waste, with intensity of $7.8^{\circ} \mathrm{C} / \mathrm{min}$, resulted in enhanced biogas production and about $6 \%$ and $24 \%$ higher COD solubilisation [97]. In another study done by Izumi et al. [98], 28\% higher biogas production was obtained using food waste when it is treated with beads mill. Ma et al. [99] has used different pretreatment techniques to kitchen waste. By adding HCL until the $\mathrm{pH}$ reduced to 2, 48\% higher methane production was reported. Meanwhile heating the same food waste at $120^{\circ} \mathrm{C}$ at 1 bar for 30 minutes gave $24 \%$ higher gas production. Again, freezing the same food waste at $-80^{\circ} \mathrm{C}$ for $6 \mathrm{~h}$ and thawing for $30 \mathrm{~min}$ result in $56 \%$ higher gas production. Applying pressure of 10 bar followed then by depressurization produces $48 \%$ more biogas.

Sometimes intensity of temperature plays a vital role in thermal pretreatment. Wang et al. [100] have reported that pretreating food waste at $70^{\circ} \mathrm{C}$ for 2 hours results in only $2.69 \%$ higher methane production while treating it for 1 hour at $150^{\circ} \mathrm{C}$ results in $11.9 \%$ higher gas production. Number of days of pretreatment could result in different rate of gas production. In an experiment conducted by Stabnikova et al. [101], total production of biogas increased up to $23.7 \%$ when freozen and thawed for 7 days. On the contrary, only mere increase was recorded when it was frozen and thawed for 12 days, that is, $8.5 \%$. In a study, when food waste and fruit and vegetable waste heated at $175^{\circ} \mathrm{C}$ for $60 \mathrm{~min}$ this showed $7.9 \%$ and $11.9 \%$ decrease in biogas production, respectively [102]. Food waste (sorted from municipal solid waste) when treated with electroporation (400 pulses) [79] yielded $20-40 \%$ higher biogas production due to substrate cell breakage. Semiaerobic and anaerobic prehydrolysis of food waste resulted in $95 \%$ COD destruction with $500 \mathrm{ml} / \mathrm{g} \mathrm{VS}$ methane yield [103]. Microaeration pretreatment [104] to the codigestion of brown water and food waste for 4 days with $37.5 \mathrm{ml} \mathrm{O}_{2} / \mathrm{L} / \mathrm{d}$ has shown $21 \%$ higher methane yield for inoculated substrate whereas only $10 \%$ higher methane yield was observed for substrate without the inoculum. 


\section{Codigestion of Food Waste}

Due to high potential for biomethanation, food waste is a reliable and promising substrate for anaerobic digestion activity. However, longer duration of digestion may sometimes lead to inhibition because of improper nutrient balance [105]. On the other hand, concentration of lipid in food waste is always higher than the limited concentration [84, 106]. To restrain this inhibition, many strategies have been adopted by researchers to codigest the food waste with cattle manure, green waste, or waste water sludge or with dairy waste. Table 5 summarizes the codigestion of FW with other organic substrates for improving performance of anaerobic process.

\section{Anaerobic Reactors}

To carry out biomethanation in practical manner, different types of reactors are required. The researchers have used different types of anaerobic reactors such as single stage and two-stage reactors, semidry reactors, solid state anaerobic reactors, upflow anaerobic solid state reactors, and hybrid reactors for the execution of biomethanation process.

Configuration of process is quite important for efficiency of methane production process. For this, single stage and twostage process have been employed for biodegradable waste treatment. Forster-Carneiro et al. [30] have reported that when all phases of anaerobic digestion, namely, hydrolysis, acidogenesis, acetogenesis, and methanogenesis, take place simultaneously in single reactor, system encounters fewer technical failures. When all polymeric compounds such as carbohydrates, protein, and fat are converted into $\mathrm{CH}_{4}, \mathrm{H}_{2} \mathrm{~S}$, $\mathrm{NH}_{3}$, and $\mathrm{CO}_{2}$ in a single vessel then that is termed as single stage reactor. Also, stability of single stage anaerobic digester for easily degradable FW is a matter of deep concern [23].

Chu et al. [107] reported that two-stage anaerobic digester has been used to produce both hydrogen and methane in two separate reactors from food waste. In this type of system, in the first stage, acidogens and hydrogen producing microorganisms which are having faster growth rate are enriched for hydrogen production and volatile fatty acid. In the second stage, acetogens and methanogens are built up where volatile fatty acids are converted into methane and carbon dioxide.

It has been reported that two-stage anaerobic digestion is providing more efficient operation as compared to single stage. Park and Li [65] have reported that highest methane recovery from kitchen waste when operated in both single stage and two-stage system was obtained as $90 \%$ (based on COD) which was determined at the OLR of $15 \mathrm{~g} \mathrm{COD} / \mathrm{L} / \mathrm{d}$. It was also reported by Massanet-Nicolau et al. [108] that methane yield from food waste increased by $37 \%$ in twostage methane fermentation process. The highest methane yields from FWs were reported by Koike et al. [109]. Biogas production of $850 \mathrm{~L} / \mathrm{g}$ VS during the two-stage hydrogen and methane production processing of FW was obtained by them.

On the other hand, solid state anaerobic digestion has several advantages over liquid anaerobic digestion in terms of smaller volume required for reactors, low material handling, low water requirement, and so forth. It has been reported that food waste is generally treated by liquid anaerobic digestion and organic fraction of municipal solid waste as well as lignocellulosic biomass can be treated by solid state anaerobic digestion [76].

Hybrid reactors also have been proposed by some researchers. In a study performed by Hai-Lou et al. [110], food waste was digested at $35^{\circ} \mathrm{C}$ for 16 days in a hybrid reactor. The result showed treatment efficiencies of $77-80 \%$ of total organic content removal, 59-60\% volatile solid removal, and $79-80 \%$ total COD reduction were achieved. Also, high methane content (68-70\%) from the methanogenic phase favors the application of hybrid anaerobic solid liquid bioreactor to practical solid waste management.

\section{Mathematical Modelling of Anaerobic Digestion}

Based on the total operating solid content, anaerobic digestion can be categorized as liquid state anaerobic digestion (LAD) $(\mathrm{TS} \leq 15 \%)$ or solid state anaerobic digestion (SS-AD) (TS $\geq 15 \%$ ) [111]. L-AD is adopted to treat liquid organic waste such as sewage sludge, animal manure, and waste water from food processing unit while SS-AD is adopted to treat solid organic material such as yard trimmings, crop residues, and organic fraction of municipal solid waste and food waste [112, 113]. As compared to L-AD, SS-AD is having advantages of solid loading capacity, more volumetric biogas productivity, and less need of energy [114].

Besides having economic and environmental benefits and being a promising technology, a major disadvantage of solid state anaerobic digestion is the low rate of reaction $[115,116]$. Slow release of soluble substrate for microbial metabolism could be the possible reason for this. Till date, SS-AD systems are operated empirically and still lacking in mechanistic tools for controlling the process [117]. Application of mathematical model can be applied to anaerobic digestion for mechanism explanation and its engineering process and parameters affecting biomethanation and their interaction with each other $[34,118]$. Many researchers have adopted mathematical modelling for optimizing anaerobic digestion activity based on theoretical, empirical, and statistical approach. In a theoretical approach, six models were adopted, namely, two-particle model [119], reaction front [120, 121], distributed model [122-126], spatial temporal model [127, 128], modified ADM 1 [129-131], and diffusion limitation [132]. Empirical approach leads to logistic modelling [133] and general kinetic modelling $[134,135]$. Also, statistical approaches such as linear regression and artificial neural network have been adopted [136-140].

Statistically derived models may emphasize prediction of system behaviour and are especially useful when there are a limited number of targeting outputs, while the models are black box models and might not provide enough information to unveil system mechanisms.

On the other hand, theoretical models provide more insight into the complex system mechanisms, while simplification is required to find general applications $[34,141]$. 
TABLE 5: Codigestion of food waste with other organic substrates.

\begin{tabular}{llll}
\hline Feedstock & Action of codigestion & Influencing factor \\
\hline FW + CM & Improve methane yield and system & $\begin{array}{l}\text { High buffering capacity and trace } \\
\text { elements supplement }\end{array}$ \\
stability & Improve methane yield and VS reduction & Higher buffering capacity \\
FW + yard waste & Improve methane yield & Less VFA accumulation \\
FW + dewatered sludge & Enhance system stability & Less inhibition from Na ${ }^{+}$ \\
FW + sewage sludge & Afford high organic loading rate & High buffering capacity from ammonia \\
FW + green waste & Improve VS reduction & C/N ratio \\
FW + brown water & Improve methane yield & High buffering capacity \\
FW + press water & Improved system stability and methane & [37] \\
FW + distiller's grain & yield & High buffering capacity \\
\hline
\end{tabular}

\section{Microbial Community Analysis}

Anaerobic digestion is the outcome of complex microbiome working in solidarity. A guild of microorganisms work on different phases of anaerobic digestion (Figure 4), maintaining a synergistic balance to ensure the stability of anaerobic digestion. However, anaerobic digesters often suffer with various instabilities pertaining to inhibition, foaming, and acidification especially at high organic load rates (OLRs) [142]. These instabilities are generally associated with the characteristics and dynamics of the microbial communities involved in anaerobic digestion process. Therefore, microbial community analysis, investigating the composition and behaviour of microbial communities, can be helpful to optimize stable and efficient process operation. The highthroughput sequencing technologies have further opened up new avenues for investigations of microbial communities during anaerobic digestion. Methods for revealing microbial community compositions are based on the generation of 16S rRNA gene clone libraries and 16S rRNA amplicons. Archaeal community are identified by targeting $m c r A$ gene. The sequence reads are then analyzed by sophisticated bioinformatics tools for taxonomic distribution and functional annotations.

Lim and Wang, [104] studied microbial community for single phase and two-phase anaerobic digestion of food waste and found predominance of Firmicutes and greater bacterial diversity in two-phase continuous stirred tank reactor that led to $23 \%$ higher methane yield in comparison to single phase anaerobic digestion. Methanosaeta dominated the archaeal community of both single phase and two-phase reactors [143]. Cho et al. [144] investigated methanogenic community during dry anaerobic digestion of food waste and observed a significant reduction in methanogen diversity after acclimation to dry AD. Almost all sequences obtained from dry anaerobic digester sludge belonged to Methanosarcina genus reported to be more tolerant to sudden change in $\mathrm{pH}$ and use both acetoclastic and hydrogenotrophic pathways, which make them more suitable for surviving in comparison to Methanosaeta. Gou et al. [58] investigated effect of temperature and organic loading rate on microbial community of food waste anaerobic digestion and found significant effect of temperature on the richness of microbial community which was more diverse at $35^{\circ} \mathrm{C}$ in comparison to $45^{\circ}$ and $55^{\circ} \mathrm{C}$. At $55^{\circ} \mathrm{C}$ only 5 species remain abundant that explains that thermophilic bacteria are more sensitive towards temperature variation.

Wan et al. [145] classified the nucleotide sequences by using the ribosomal database project classifier software and showed that Proteobacteria, Firmicutes, and Bacteroidetes were the most abundant microorganisms during the entire process of anaerobic digestion. The diversity of microorganisms significantly increased during active methanogenesis in comparison to day 0, with addition of Synergistetes, Tenericutes, Spirochaetes, and Actinobacteria. Li et al. [142, 146] introduced disturbance in OLR into mesophilic anaerobic digester and carried out microbial community analysis during stable and deteriorative phases by employing pyrosequencing. Microbial communities were investigated using 454 pyrosequencing. Raw sequences were quality checked by mothur software and aligned with SILVA alignment. In his study, the acidogenic bacteria and syntrophic VFA oxidizers were found abundantly in deteriorative phase suggesting that, during high OLR, hydrolysis and acidogenesis surpassed the rate of methanogenesis which led to the irreversible acidification of accumulated VFAs.

Zamanzadeh et al. [147] investigated the effect of digestate recirculation on microbial community by using Illumina sequencing. Taxonomic assignment of sequences was done by using QIIME's uclust-based taxonomy assigner. Proteobacteria, Firmicutes, Chloroflexi, and Bacteroidetes were found to be the dominant bacterial phyla in both digester configuration types (with and without recirculation). Methanosaeta and Methanobacterium were dominant genera among archaeal population, accounting for $65 \%$ and $32 \%$ of Euryarchaeota's reads in mesophilic digester without recirculation, while, in digester with digestate recirculation, Methanosaeta accounted for $91 \%$ of all Euryarchaeota's. These results show the prevalence of acetoclastic methanogens over hydrogenotrophic methanogens, which acknowledge acetate reduction as the main pathway of methane formation. Similarly, Gulhane et al. [148] studied the microbial community under effect of no digestate recirculation, 25\% digestate recirculation, and $100 \%$ digestate recirculation. Illumina 


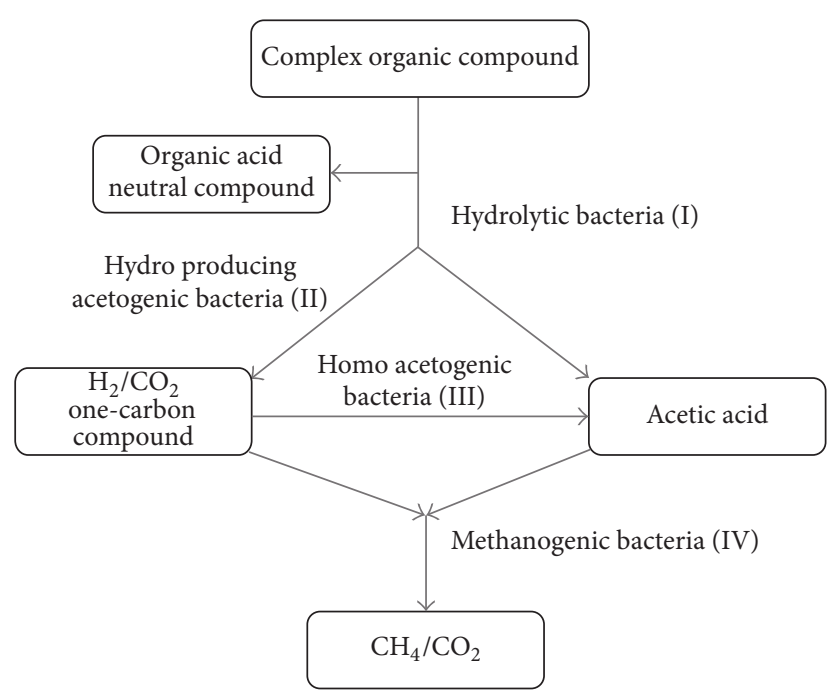

FIGURE 4: Significance of the microbial population in anaerobic digester.

sequenced reads were pair assembled using PANDAseq and mothur software was used to align and filter and trim and remove chimeras and classify and assign taxonomy. The result revealed the domination of hydrolytic and fermentative phyla in digester with no digestate recirculation, while syntrophic acetogenic bacteria dominated the digester with recirculation.

Guo et al. [149] carried out comparative analysis of the microbial community response to increasing OLR in mesophilic and thermophilic reactor and reported that mesophilic reactor had greater richness of microorganisms in comparison to thermophilic reactor. They also reported the dominance of Methanosaeta in archaeal community in mesophilic reactor while presence of Methanothermobacter and Methanoculleus were favored in thermophilic reactor.

\section{Metagenomic Tool and Techniques for Advance Practices}

In a fast-growing world, food wastage and its management are one of the major challenges faced by our society due to inherited high risk for human health and increasing environmental burdens. Strategic use of biodegradation processing on food waste can turn out into multiple societal benefits. Production of energy, that is, biogas through biomass of food waste, could be of major interest for easy storage and transport. Secondly, it reduces the hazardous effects on environment through the multiple layered food wastes processing and management. Production of soil additives and liquid fertilizers from organic food waste will be direct incentive from food waste management. Various $16 \mathrm{~S}$ and $18 \mathrm{~S}$ rRNAbased fragmented studies were performed through researcher for waste management treatment and microbial communities were identified from all the three taxonomic units of the microbial world, that is, Archaea, Bacteria, and Eukarya. In total, 4133 methanogenic bacteria were classified into Archaea domain and Crenarchaeota and Euryarchaeota are most visible group [33]. Methanogens have huge morphological diversity: cocci (Methanococcus), Spirillaceae (Methanospirillum), Sarcina (Methanosarcina), rods (Methanobacterium), short rods (Methanobrevibacter), and filiforms (Methanothrix) [150]. Acetotrophic methanogens are the main obligatory anaerobes belonging to genus Methanosarcina which are involved in the processing of acetate to methane and carbon dioxide. Methanobacteriaceae family have been found associated with hydrogen binding methanogenic bacteria. Methanosphaera stadtmaniae and Methanobrevibacter wolinii are the two main groups of hydrogenotrophic microorganisms participating in anaerobic processing of fruit and vegetable [151].

The knowledge of the link between taxonomical and functional diversity and species richness can be a key for better understanding of ecosystem functioning in waste food treatment. Molecular methods like PCR, RFLP, microarrays, and sequencing have been utilized in the field of waste management. But these methods have own limitations for large scale functional characterization of ecological systems. Recently, captured metagenomics demonstrated the potential of functional characterization of microbial communities of agricultural soil on a large scale through NGS. Application of these approaches for food waste management can improve our understanding about treatment and enhance quality of treatment and management products [152]. Microbial communities can be used in more efficient manner in food waste management through exploration of available microbial resources and strategic use of available advance metagenomics practices.

11.1. Microarrays. Microarray is a one of the easiest and powerful tools to characterize differences in gene content between organisms and gene expression. Microarray technique has become popular due to large scale sequencing of microbial genomes year after year. Hundreds of microbial microarray based studies have been 


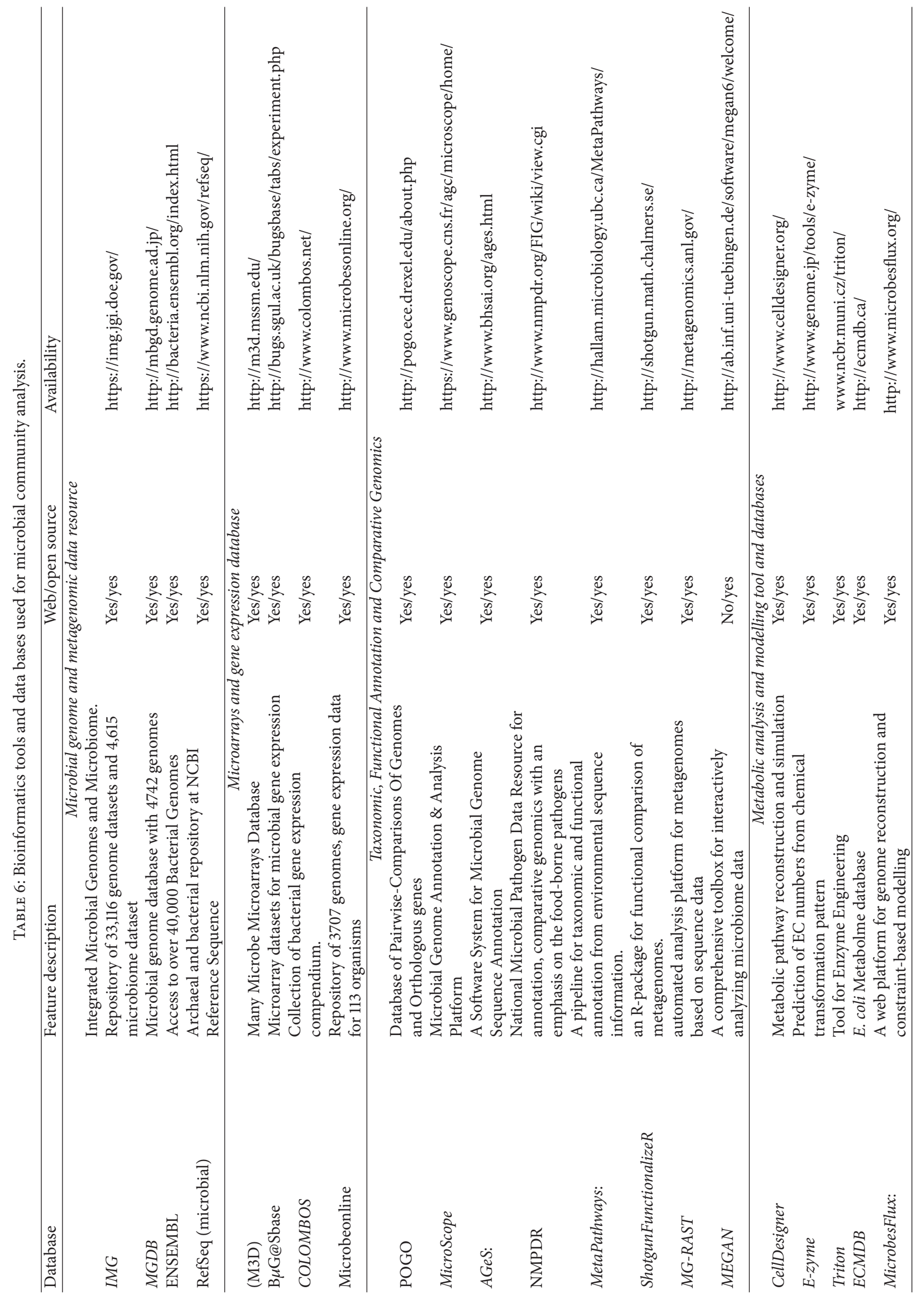




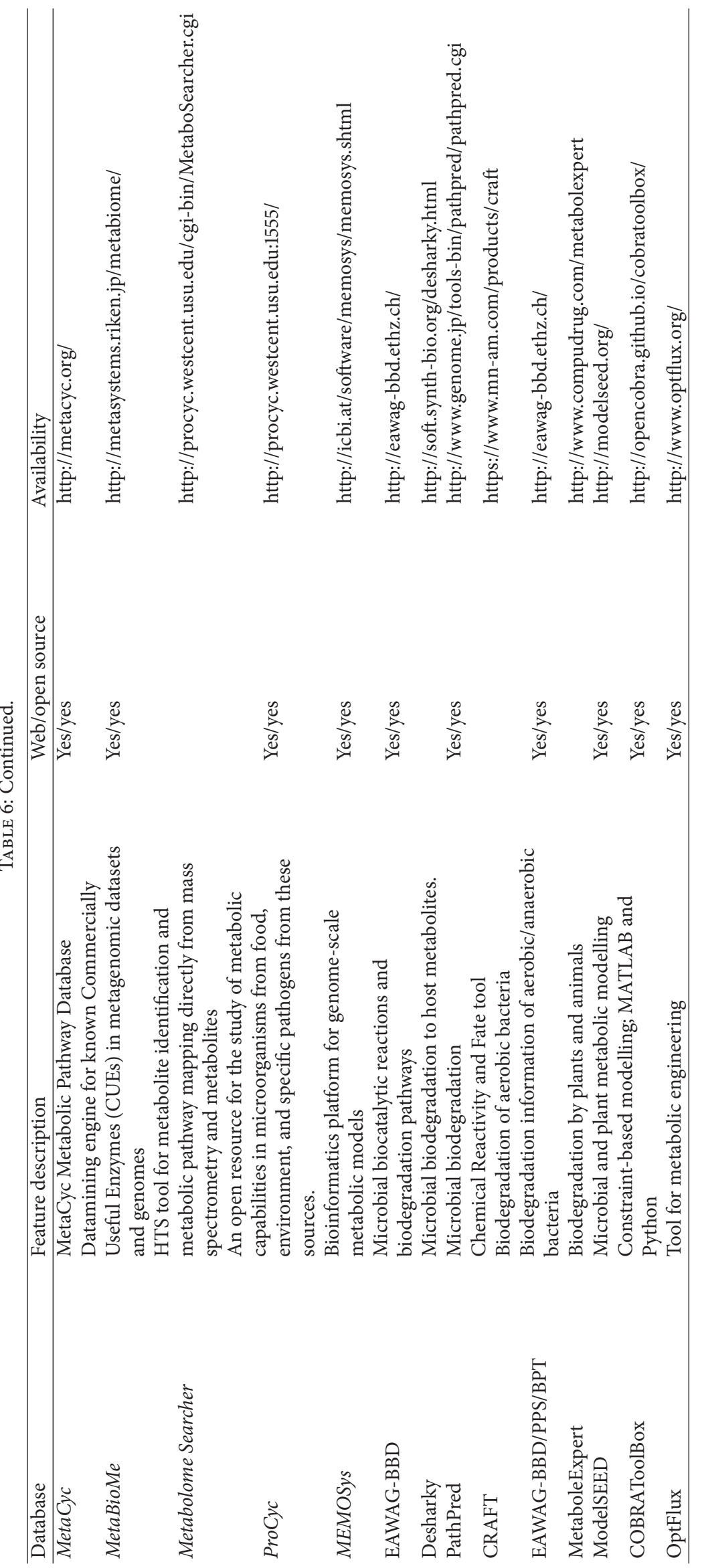


published such as $16 \mathrm{~S}$ rRNA-based taxonomic microarray for Proteobacteria [153] and Alphaproteobacteria [154], Actinomycetes microarray [155], Bacillus-PhyloChip [156], Burkholderia-PhyloChip [157], ECC-PhyloChip [158], Compost Community-Microarray [159], Freshwater SedimentMicroarray [160], Soil microbial community PhyloChip [161], SRP-PhyloChip [162], and Nitrifier-Microarray [163]. Recent advancement in sequencing and molecular technologies has opened the doors for metagenomic studies. Captured metagenomics is one example for high resolution study for soil metagenomes $[152,164]$.

11.2. Next-Generation Sequencing. The high-throughput next-generation sequencing (HT-NGS) technologies produce a lot more data compared to capillary sequencing based method. Sequencing technology revolution started with Roche 454 GS FLX+ and currently it can produce relatively long read length (approx. $700 \mathrm{bp}$ ) and low number of reads (approx. 1 million reads/run) and is used for different applications such as examining $16 \mathrm{~S}$ variable regions, targeted amplicon sequences, microbial genomes, BACs, and plastids. Illumina is one of the biggest players in the sequencing market with their versatile range of instruments and is ideal for genome sequencing and resequencing, transcriptome sequencing, SNP detection, and metagenomic studies. Illumina read length (50-300 bp) and read number (25 Million-6 billion per run) vary from platform to platform [165]. Ion Torrent technology (Ion PGM and Ion proton) is relatively new and semiconductor based sequencing platform. Potential of the platform varies with respect to the semiconductor chip that is used, that is, Ion $314^{\mathrm{TM}}$ Chip v2, Ion $316^{\mathrm{TM}}$ Chip v2, and Ion $318^{\mathrm{TM}}$ Chip v2 (read length: $200-400 \mathrm{bp}$, reads/run: $500 \mathrm{~K}-$ 5 million). It is used for various sequencing applications such as amplicons, small genomes, and targeted genomic sequencing. Automated workflow from sample preparation to analysis makes it ideal for smaller sized studies and routine practices [166]. PacBio RS have been developed for long read lengths through single molecule real-time sequencing technology, which can generate reads from $1 \mathrm{~kb}$ up to $60 \mathrm{~Kb}$. Each SMRT cell can generate approx. 50,000 reads. Longer read length feature makes it ideal for sequencing small genomes such as bacteria or viruses, regions of high G/C content and DNA with modified bases (methylation, hydroxymethylation), resequencing projects and so forth [167].

11.3. Bioinformatics Resources. In 1970, Paulien Hogeweg and Ben Hesper coined the term "bioinformatics" for the study of information processes in biological systems as technique. Currently, bioinformatics is enormously integrated in almost all biological fields. The success of bioinformatics is mainly due to the recent advancements in computational resources and infrastructure across the globe which has facilitated bioinformatics research on complex biological systems [168].

Molecular insight in the diversity of the microbial communities is a relatively young field as not much was known about it prior to 1975 due to the unavailability of advance methods, tool, and techniques [169]. The advancement of sequencing and computational technology promoted metagenomics researches which increased the bioinformatics outreach in microbial informatics and experimentation. Further development of the bioinformatics methods resulted in a large number of databases, tools, and data formats for the analysis of microorganism and microbiome related studies which enhanced our knowledge and understanding of microbial populations [170]. In recent years, the advancement of high-throughput next-generation sequencing (NGS) platforms has enabled large scale sequencing efforts for the exploration of microbial ecosystems. Consequently, the microbial ecological analysis in the near future will need a paradigm shift from data generation to data management and sharing and hypothesis driven and targeted data generation [171], in silico generated knowledge coding, mining, and networking to improve our encoded models for new knowledge discovery $[172,173]$. Here (Table 6) we have reviewed major microbial databases and tools that can be useful for microbial research application in emerging applied fields like food waste management and applications.

\section{Conclusions}

Proper disposal of food waste has posed a stern pecuniary and environmental concern. It appears that conversion of food waste into energy via anaerobic processes in terms of methane is economically viable. However, difficulties accompanying the collection as well as transportation of food waste should also be considered. Nevertheless, the stumpy or no cost of food waste along with the environmental aids considering the waste discarding would balance the initial high investment costs of the biorefineries. Moreover, the efficacy and cost base of the generation could be upgraded by intensifying research and optimization studies on assimilating different value-added product manufacturing processes.

\section{Competing Interests}

The authors declare that they have no conflict of interests.

\section{Acknowledgments}

The authors would like to thank Department of Biotechnology and Department of Sciences and Technology, Government of India.

\section{References}

[1] FAO, Towards the Future we Want: End Hunger and Make the Transition to Sustainable Agricultural and Food Systems, Food and Agriculture Organization of the United Nations Rome, 2012.

[2] M. Melikoglu, C. S. K. Lin, and C. Webb, "Analysing global food waste problem: pinpointing the facts and estimating the energy content," Central European Journal of Engineering, vol. 3, no. 2, pp. 157-164, 2013.

[3] A. Agarwal, A. Singhmar, M. Kulshrestha, and A. K. Mittal, "Municipal solid waste recycling and associated markets in Delhi, India," Resources, Conservation and Recycling, vol. 44, no. 1, pp. 73-90, 2005. 
[4] K. N. Kumar and S. Goel, "Characterization of Municipal Solid Waste (MSW) and a proposed management plan for Kharagpur, West Bengal, India," Resources, Conservation and Recycling, vol. 53, no. 3, pp. 166-174, 2009.

[5] S. Kumar, J. K. Bhattacharyya, A. N. Vaidya, T. Chakrabarti, S. Devotta, and A. B. Akolkar, "Assessment of the status of municipal solid waste management in metro cities, state capitals, class I cities, and class II towns in India: an insight," Waste Management, vol. 29, no. 2, pp. 883-895, 2009.

[6] S. Pattnaik and M. V. Reddy, "Assessment of municipal solid waste management in Puducherry (Pondicherry), India," Resources, Conservation and Recycling, vol. 54, no. 8, pp. 512520, 2010.

[7] V. Talyan, R. P. Dahiya, and T. R. Sreekrishnan, "State of municipal solid waste management in Delhi, the capital of India," Waste Management, vol. 28, no. 7, pp. 1276-1287, 2008.

[8] T. Katami, A. Yasuhara, and T. Shibamoto, "Formation of dioxins from incineration of foods found in domestic garbage," Environmental Science and Technology, vol. 38, no. 4, pp. 10621065, 2004.

[9] H. Ma, Q. Wang, D. Qian, L. Gong, and W. Zhang, "The utilization of acid-tolerant bacteria on ethanol production from kitchen garbage," Renewable Energy, vol. 34, no. 6, pp. 14661470, 2009.

[10] T. N. B. Dung, B. Sen, C. C. Chen, G. Kumar, and C. Y. Lin, "Food waste to bioenergy via anaerobic processes," Energy Procedia, vol. 61, pp. 307-312, 2014.

[11] FAO, FAOSTAT: World Food and Agriculture Statistical Yearbook, FAO-Food \& Agriculture Organization of the United Nation, Rome, Italy, 2013.

[12] I. M. Nasir, T. I. M. Ghazi, and R. Omar, "Production of biogas from solid organic wastes through anaerobic digestion: a review," Applied Microbiology and Biotechnology, vol. 95, no. 2, pp. 321-329, 2012.

[13] M. Morita and K. Sasaki, "Factors influencing the degradation of garbage in methanogenic bioreactors and impacts on biogas formation," Applied Microbiology and Biotechnology, vol. 94, no. 3, pp. 575-582, 2012.

[14] Y. Ohkouchi and Y. Inoue, "Direct production of L(+)-lactic acid from starch and food wastes using Lactobacillus manihotivorans LMG18011," Bioresource Technology, vol. 97, no. 13, pp. 1554-1562, 2006.

[15] Y.-Q. Tang, Y. Koike, K. Liu et al., "Ethanol production from kitchen waste using the flocculating yeast Saccharomyces cerevisiae strain KF-7," Biomass and Bioenergy, vol. 32, no. 11, pp. 1037-1045, 2008.

[16] Q. Wang, H. Ma, W. Xu, L. Gong, W. Zhang, and D. Zou, "Ethanol production from kitchen garbage using response surface methodology," Biochemical Engineering Journal, vol. 39, no. 3, pp. 604-610, 2008.

[17] B. Zhang, Z.-G. He, L.-L. Zhang, J.-B. Xu, H.-Z. Shi, and W.-M. Cai, "Anaerobic digestion of kitchen wastes in a single-phased anaerobic sequencing batch reactor (ASBR) with gas-phased absorb of $\mathrm{CO}_{2}$," Journal of Environmental Sciences, vol. 17, no. 2, pp. 249-255, 2005.

[18] H. Ma, Q. Wang, W. Zhang, W. Xu, and D. Zou, “Optimization of the medium and process parameters for ethanol production from kitchen garbage by Zymomonas mobilis," International Journal of Green Energy, vol. 5, no. 6, pp. 480-490, 2008.

[19] O. N. Uncu and D. Cekmecelioglu, "Cost-effective approach to ethanol production and optimization by response surface methodology," Waste Management, vol. 31, no. 4, pp. 636-643, 2011.

[20] M. He, Y. Sun, D. Zou et al., "Influence of temperature on hydrolysis acidification of food waste," Procedia Environmental Sciences, vol. 16, pp. 85-94, 2012.

[21] A. I. Vavouraki, E. M. Angelis, and M. Kornaros, "Optimization of thermo-chemical hydrolysis of kitchen wastes," Waste Management, vol. 33, no. 3, pp. 740-745, 2013.

[22] L. Zhang and D. Jahng, "Long-term anaerobic digestion of food waste stabilized by trace elements," Waste Management, vol. 32, no. 8, pp. 1509-1515, 2012.

[23] J. P. Lee, J. S. Lee, and S. C. Park, "Two-phase methanization of food wastes in pilot scale," Applied Biochemistry and Biotechnology, vol. 77-79, pp. 585-593, 1999.

[24] V. N. Gunaseelan, "Biochemical methane potential of fruits and vegetable solid waste feedstocks," Biomass and Bioenergy, vol. 26, no. 4, pp. 389-399, 2004.

[25] J.-H. Youn and H.-S. Shin, "Comparative performance between temperature-phased and conventional mesophilic two-phased processes in terms of anaerobically produced bioenergy from food waste," Waste Management and Research, vol. 23, no. 1, pp. 32-38, 2005.

[26] C. J. Banks, M. Chesshire, S. Heaven, and R. Arnold, "Anaerobic digestion of source-segregated domestic food waste: performance assessment by mass and energy balance," Bioresource Technology, vol. 102, no. 2, pp. 612-620, 2011.

[27] H. C. Moon and I. S. Song, "Enzymatic hydrolysis of foodwaste and methane production using UASB bioreactor," International Journal of Green Energy, vol. 8, no. 3, pp. 361-371, 2011.

[28] X. Dai, N. Duan, B. Dong, and L. Dai, "High-solids anaerobic co-digestion of sewage sludge and food waste in comparison with mono digestions: stability and performance," Waste Management, vol. 33, no. 2, pp. 308-316, 2013.

[29] C. Zhang, G. Xiao, L. Peng, H. Su, and T. Tan, "The anaerobic co-digestion of food waste and cattle manure," Bioresource Technology, vol. 129, pp. 170-176, 2013.

[30] T. Forster-Carneiro, M. Pérez, and L. I. Romero, "Influence of total solid and inoculum contents on performance of anaerobic reactors treating food waste," Bioresource Technology, vol. 99, no. 15, pp. 6994-7002, 2008.

[31] D.-H. Kim, S.-H. Kim, K.-Y. Kim, and H.-S. Shin, "Experience of a pilot-scale hydrogen-producing anaerobic sequencing batch reactor (ASBR) treating food waste," International Journal of Hydrogen Energy, vol. 35, no. 4, pp. 1590-1594, 2010.

[32] J. K. Kim, G. H. Han, B. R. Oh, Y. N. Chun, C.-Y. Eom, and S. W. Kim, "Volumetric scale-up of a three stage fermentation system for food waste treatment," Bioresource Technology, vol. 99, no. 10, pp. 4394-4399, 2008.

[33] K. Ziemiński and M. Frąc, "Methane fermentation process as anaerobic digestion of biomass: transformations, stages and microorganisms," African Journal of Biotechnology, vol. 11, no. 18, pp. 4127-4139, 2012.

[34] J. Lauwers, L. Appels, I. P. Thompson, J. Degrève, J. F. Van Impe, and R. Dewil, "Mathematical modelling of anaerobic digestion of biomass and waste: power and limitations," Progress in Energy and Combustion Science, vol. 39, no. 4, pp. 383-402, 2013.

[35] D.-H. Kim and S.-E. Oh, "Continuous high-solids anaerobic codigestion of organic solid wastes under mesophilic conditions," Waste Management, vol. 31, no. 9-10, pp. 1943-1948, 2011.

[36] D. Brown and Y. Li, "Solid state anaerobic co-digestion of yard waste and food waste for biogas production," Bioresource Technology, vol. 127, pp. 275-280, 2013. 
[37] H.-W. Kim, J.-Y. Nam, and H.-S. Shin, "A comparison study on the high-rate co-digestion of sewage sludge and food waste using a temperature-phased anaerobic sequencing batch reactor system," Bioresource Technology, vol. 102, no. 15, pp. 7272-7279, 2011.

[38] M. Kumar, Y.-L. Ou, and J.-G. Lin, "Co-composting of green waste and food waste at low C/N ratio," Waste Management, vol. 30, no. 4, pp. 602-609, 2010.

[39] R. Rajagopal, J. W. Lim, Y. Mao, C.-L. Chen, and J.-Y. Wang, "Anaerobic co-digestion of source segregated brown water (feces-without-urine) and food waste: for Singapore context," Science of the Total Environment, vol. 443, pp. 877-886, 2013.

[40] S. E. Nayono, C. Gallert, and J. Winter, "Co-digestion of press water and food waste in a biowaste digester for improvement of biogas production," Bioresource Technology, vol. 101, no. 18, pp. 6987-6993, 2010

[41] L.-H. Wang, Q. Wang, W. Cai, and X. Sun, "Influence of mixing proportion on the solid-state anaerobic co-digestion of distiller's grains and food waste," Biosystems Engineering, vol. 112, no. 2, pp. 130-137, 2012.

[42] K. M. Mittal, Biogas Systems, Policies, Progress and Prospects, New Age International, New Delhi, India, 1997.

[43] M. P. Bryant, "Microbial methane production: theoretical aspects," Journal of Animal Science, vol. 48, no. 1, pp. 193-201, 1979.

[44] B. Schink, "Energetics of syntrophic cooperation in methanogenic degradation," Microbiology and Molecular Biology Reviews, vol. 61, no. 2, pp. 262-280, 1997.

[45] M. E. Griffin, K. D. McMahon, R. I. Mackie, and L. Raskin, "Methanogenic population dynamics during start-up of anaerobic digesters treating municipal solid waste and biosolids," Biotechnology and Bioengineering, vol. 57, no. 3, pp. 342-355, 1998.

[46] D. Karakashev, D. J. Batstone, and I. Angelidaki, "Influence of environmental conditions on methanogenic compositions in anaerobic biogas reactors," Applied and Environmental Microbiology, vol. 71, no. 1, pp. 331-338, 2005.

[47] A. M. Viturtia, J. Mata-Alvarez, F. Cecchi, and G. Fazzini, “Twophase anaerobic digestion of a mixture of fruit and vegetable wastes," Biological Wastes, vol. 29, no. 3, pp. 189-199, 1989.

[48] J. K. Cho, S. C. Park, and H. N. Chang, "Biochemical methane potential and solid state anaerobic digestion of Korean food wastes," Bioresource Technology, vol. 52, no. 3, pp. 245-253, 1995.

[49] Z. Yong, Y. Dong, X. Zhang, and T. Tan, "Anaerobic co-digestion of food waste and straw for biogas production," Renewable Energy, vol. 78, pp. 527-530, 2015.

[50] N. Curry and P. Pillay, "Biogas prediction and design of a food waste to energy system for the urban environment," Renewable Energy, vol. 41, pp. 200-209, 2012.

[51] R. E. Anderson, Biological Path to Self-Reliance, Van Nostrand Reinhold Company, New York, NY, USA, 1979.

[52] P. Dhevagi, K. Ramasamy, and G. Oblisami, Biological Nitrogen Fixation and Biogas Technology, Tamilnadu Agricultural University, 1992.

[53] S. H. Zinder, "Physiological ecology of methanogens," in Methanogenesis: Ecology, Physiology, Biochemistry, and Genetics, J. G. Ferry, Ed., pp. 128-206, Chapman and Hall, New York, NY, USA, 1993.

[54] L. Arsova, Anaerobic digestion of food waste: current status, problems and an alternative product [M.S. thesis], Columbia University, Berlin, Germany, 2010.
[55] A. C. Van Haandel and G. Lettinga, Anaerobic Sewage Treatment-A Practical Guide for Regions with a Hot Climate, John Wiley \& Sons, New York, NY, USA, 1994.

[56] H. Bouallagui, O. Haouari, Y. Touhami, R. Ben Cheikh, L. Marouani, and M. Hamdi, "Effect of temperature on the performance of an anaerobic tubular reactor treating fruit and vegetable waste," Process Biochemistry, vol. 39, no. 12, pp. 21432148, 2004.

[57] J. K. Kim, B. R. Oh, Y. N. Chun, and S. W. Kim, "Effects of temperature and hydraulic retention time on anaerobic digestion of food waste," Journal of Bioscience and Bioengineering, vol. 102, no. 4, pp. 328-332, 2006.

[58] C. Gou, Z. Yang, J. Huang, H. Wang, H. Xu, and L. Wang, "Effects of temperature and organic loading rate on the performance and microbial community of anaerobic co-digestion of waste activated sludge and food waste," Chemosphere, vol. 105, pp. 146-151, 2014.

[59] X. Wang, G. Yang, Y. Feng, G. Ren, and X. Han, “Optimizing feeding composition and carbon-nitrogen ratios for improved methane yield during anaerobic co-digestion of dairy, chicken manure and wheat straw," Bioresource Technology, vol. 120, pp. 78-83, 2012.

[60] D. H. Lee, S. K. Behera, J. W. Kim, and H.-S. Park, "Methane production potential of leachate generated from Korean food waste recycling facilities: a lab-scale study," Waste Management, vol. 29, no. 2, pp. 876-882, 2009.

[61] R. Goel, T. Tokutomi, and H. Yasui, "Anaerobic digestion of excess activated sludge with ozone pretreatment," Water Science and Technology, vol. 47, no. 12, pp. 207-214, 2003.

[62] K. M. Mittal, Biogas Systems: Principles and Application, New Age International, New Delhi, India, 1996.

[63] Zeshan, O. P. Karthikeyan, and C. Visvanathan, "Effect of $\mathrm{C} / \mathrm{N}$ ratio and ammonia- $\mathrm{N}$ accumulation in a pilot-scale thermophilic dry anaerobic digester," Bioresource Technology, vol. 113, pp. 294-302, 2012.

[64] W. Zhong, L. Chi, Y. Luo, Z. Zhang, Z. Zhang, and W.-M. Wu, "Enhanced methane production from Taihu Lake blue algae by anaerobic co-digestion with corn straw in continuous feed digesters," Bioresource Technology, vol. 134, pp. 264-270, 2013.

[65] S. Park and Y. Li, "Evaluation of methane production and macronutrient degradation in the anaerobic co-digestion of algae biomass residue and lipid waste," Bioresource Technology, vol. 111, pp. 42-48, 2012.

[66] H.-W. Yen and D. E. Brune, "Anaerobic co-digestion of algal sludge and waste paper to produce methane," Bioresource Technology, vol. 98, no. 1, pp. 130-134, 2007.

[67] J. Van Brakel, The Ignis Fatuus of Biogas Small-Scale Anaerobic Digesters ('Biogas Plants'): A Critical Review of the Pre-1970 Literature, Delft University Press, 1980.

[68] I. Siegert and C. Banks, "The effect of volatile fatty acid additions on the anaerobic digestion of cellulose and glucose in batch reactors," Process Biochemistry, vol. 40, no. 11, pp. 3412-3418, 2005.

[69] K. Vijayaraghavan, V. S. Varma, and S. P. Kamala Nalini, "Hydrogen generation from biological solid waste of milk processing effluent treatment plan," International Journal of Current Trends and Resources, vol. 1, pp. 17-23, 2012.

[70] R. A. Labatut, L. T. Angenent, and N. R. Scott, "Biochemical methane potential and biodegradability of complex organic substrates," Bioresource Technology, vol. 102, no. 3, pp. 22552264, 2011. 
[71] H. Bouallagui, Y. Touhami, R. Ben Cheikh, and M. Hamdi, "Bioreactor performance in anaerobic digestion of fruit and vegetable wastes," Process Biochemistry, vol. 40, no. 3-4, pp. 989995, 2005.

[72] P. D. Cotter and C. Hill, "Surviving the acid test: responses of gram-positive bacteria to low pH," Microbiology and Molecular Biology Reviews, vol. 67, no. 3, pp. 429-453, 2003.

[73] B. Zhang, L.-L. Zhang, S.-C. Zhang, H.-Z. Shi, and W.-M. Cai, "The influence of $\mathrm{pH}$ on hydrolysis and acidogenesis of kitchen wastes in two-phase anaerobic digestion," Environmental Technology, vol. 26, no. 3, pp. 329-339, 2005.

[74] J. A. Eastman and J. F. Ferguson, "Solubilisation of particulate organic carbon during theacid phase of AD," Journal of the Water Pollution Control Federation, vol. 53, pp. 352-366, 1981.

[75] E. P. Taiganides, "Biomass-energy recovery from animal waste Part I," World Animal Review, vol. 35, p. 2, 1980.

[76] N. Nagao, N. Tajima, M. Kawai et al., "Maximum organic loading rate for the single-stage wet anaerobic digestion of food waste," Bioresource Technology, vol. 118, pp. 210-218, 2012.

[77] E. Tampio, S. Ervasti, T. Paavola, S. Heaven, C. Banks, and J. Rintala, "Anaerobic digestion of autoclaved and untreated food waste," Waste Management, vol. 34, no. 2, pp. 370-377, 2014.

[78] F. O. Agyeman and W. Tao, "Anaerobic co-digestion of food waste and dairy manure: effects of food waste particle size and organic loading rate," Journal of Environmental Management, vol. 133, pp. 268-274, 2014.

[79] M. Carlsson, A. Lagerkvist, and H. Ecke, "Electroporation for enhanced Methane yield from municipal solid waste," in Proceedings of the Moving Organic Waste Recycling Towards Resource Management and Biobased Economy (ORBIT '08), vol. 6, pp. 1-8, Wageningen, the Netherlands, October 2008.

[80] L. H. Hagen, V. Vivekanand, R. Linjordet, P. B. Pope, V. G. H. Eijsink, and S. J. Horn, "Microbial community structure and dynamics during co-digestion of whey permeate and cow manure in continuous stirred tank reactor systems," Bioresource Technology, vol. 171, pp. 350-359, 2014.

[81] O. Yenigün and B. Demirel, "Ammonia inhibition in anaerobic digestion: a review," Process Biochemistry, vol. 48, no. 5-6, pp. 901-911, 2013.

[82] M. J. Whelan, T. Everitt, and R. Villa, "A mass transfer model of ammonia volatilisation from anaerobic digestate," Waste Management, vol. 30, no. 10, pp. 1808-1812, 2010.

[83] M. Walker, K. Iyer, S. Heaven, and C. J. Banks, "Ammonia removal in anaerobic digestion by biogas stripping: an evaluation of process alternatives using a first order rate model based on experimental findings," Chemical Engineering Journal, vol. 178, pp. 138-145, 2011.

[84] C. Zhang, H. Su, and T. Tan, "Batch and semi-continuous anaerobic digestion of food waste in a dual solid-liquid system," Bioresource Technology, vol. 145, pp. 10-16, 2013.

[85] F. Raposo, V. Fernández-Cegrí, M. A. de la Rubia et al., "Biochemical methane potential (BMP) of solid organic substrates: evaluation of anaerobic biodegradability using data from an international interlaboratory study," Journal of Chemical Technology and Biotechnology, vol. 86, no. 8, pp. 1088-1098, 2011.

[86] P. Jin, S. K. Bhattacharya, C. J. Williams, and H. Zhang, "Effects of sulfide addition on copper inhibition in methanogenic systems," Water Research, vol. 32, no. 4, pp. 977-988, 1998.

[87] A. Schattauer, E. Abdoun, P. Weiland, M. Plöchl, and M. Heiermann, "Abundance of trace elements in demonstration biogas plants," Biosystems Engineering, vol. 108, no. 1, pp. 57-65, 2011.
[88] V. Facchin, C. Cavinato, F. Fatone, P. Pavan, F. Cecchi, and D. Bolzonella, "Effect of trace element supplementation on the mesophilic anaerobic digestion of foodwaste in batch trials: the influence of inoculum origin," Biochemical Engineering Journal, vol. 70, pp. 71-77, 2013.

[89] C. A. Jackson-Moss, J. R. Duncan, and D. R. Cooper, “The effect of calcium on anaerobic digestion," Biotechnology Letters, vol. 11, no. 3, pp. 219-224, 1989.

[90] H. Q. Yu, J. H. Tay, and H. H. P. Fang, "The roles of calcium in sludge granulation during UASB reactor start-up," Water Research, vol. 35, no. 4, pp. 1052-1060, 2001.

[91] C.-Y. Lin and C.-C. Chen, "Effect of heavy metals on the methanogenic UASB granule," Water Research, vol. 33, no. 2, pp. 409-416, 1999.

[92] G. Zayed and J. Winter, "Inhibition of methane production from whey by heavy metals-protective effect of sulfide," Applied Microbiology and Biotechnology, vol. 53, no. 6, pp. 726-731, 2000.

[93] S. Ghosh, M. P. Henry, and R. W. Christopher, "Hemicellulose conversion by anaerobic digestion," Biomass, vol. 6, no. 4, pp. 257-269, 1985.

[94] E. Elbeshbishy, G. Nakhla, and H. Hafez, "Biochemical methane potential (BMP) of food waste and primary sludge: influence of inoculum pre-incubation and inoculum source," Bioresource Technology, vol. 110, pp. 18-25, 2012.

[95] M. S. Lisboa and S. Lansing, "Characterizing food waste substrates for co-digestion through biochemical methane potential (BMP) experiments," Waste Management, vol. 33, no. 12, pp. 2664-2669, 2013.

[96] M. Murto, L. Björnsson, H. Rosqvist, and I. Bohn, "Evaluating the biogas potential of the dry fraction from pretreatment of food waste from households," Waste Management, vol. 33, no. 5, pp. 1282-1289, 2013.

[97] J. Marin, K. J. Kennedy, and C. Eskicioglu, "Effect of microwave irradiation on anaerobic degradability of model kitchen waste," Waste Management, vol. 30, no. 10, pp. 1772-1779, 2010.

[98] K. Izumi, Y. K. Okishio, C. Niwa, S. Yamamoto, and T. Toda, "Effects of particle size on anaerobic digestion of food waste," International Journal of Bio-Deterioration Biodegradation, vol. 64, no. 7, pp. 601-608, 2010.

[99] J. Ma, T. H. Duong, M. Smits, W. Verstraete, and M. Carballa, "Enhanced biomethanation of kitchen waste by different pretreatments," Bioresource Technology, vol. 102, no. 2, pp. 592-599, 2011.

[100] J.-Y. Wang, X.-Y. Liu, J. C. M. Kao, and O. Stabnikova, "Digestion of pre-treated food waste in a hybrid anaerobic solidliquid (HASL) system," Journal of Chemical Technology and Biotechnology, vol. 81, no. 3, pp. 345-351, 2006.

[101] O. Stabnikova, X. Y. Liu, and J. Y. Wang, "Digestion of frozen/thawed food waste in the hybrid anaerobic solid-liquid system," Waste Management, vol. 28, no. 9, pp. 1654-1659, 2008.

[102] X. Liu, W. Wang, X. Gao, Y. Zhou, and R. Shen, "Effect of thermal pretreatment on the physical and chemical properties of municipal biomass waste," Waste Management, vol. 32, no. 2, pp. 249-255, 2012.

[103] S. W. Kim, J. Y. Park, J. K. Kim et al., "Development of a modified three-stage methane production process using food wastes," Applied Biochemistry and Biotechnology, vol. 84-86, pp. 731-741, 2000.

[104] J. W. Lim and J.-Y. Wang, "Enhanced hydrolysis and methane yield by applying microaeration pretreatment to the anaerobic co-digestion of brown water and food waste," Waste Management, vol. 33, no. 4, pp. 813-819, 2013. 
[105] L. Neves, R. Oliveira, and M. M. Alves, "Co-digestion of cow manure, food waste and intermittent input of fat," Bioresource Technology, vol. 100, no. 6, pp. 1957-1962, 2009.

[106] S. G. Kim, "System for separation of oil and sludge from food waste leachate," Korea Patent 10-2010-0053719.

[107] C.-F. Chu, Y.-Y. Li, K.-Q. Xu, Y. Ebie, Y. Inamori, and H.-N. Kong, "A pH- and temperature-phased two-stage process for hydrogen and methane production from food waste," International Journal of Hydrogen Energy, vol. 33, no. 18, pp. 4739-4746, 2008.

[108] J. Massanet-Nicolau, R. Dinsdale, A. Guwy, and G. Shipley, "Use of real time gas production data for more accurate comparison of continuous single-stage and two-stage fermentation," Bioresource Technology, vol. 129, pp. 561-567, 2013.

[109] Y. Koike, M.-Z. An, Y.-Q. Tang et al., "Production of fuel ethanol and methane from garbage by high-efficiency two-stage fermentation process," Journal of Bioscience and Bioengineering, vol. 108, no. 6, pp. 508-512, 2009.

[110] X. Hai-Lou, W. Jing-Yuan, and T. Joo-Hwa, "A hybrid anaerobic solid-liquid bioreactor for food waste digestion," Biotechnology Letters, vol. 24, no. 10, pp. 757-761, 2002.

[111] Y. Li, S. Y. Park, and J. Zhu, "Solid-state anaerobic digestion for methane production from organic waste," Renewable and Sustainable Energy Reviews, vol. 15, no. 1, pp. 821-826, 2011.

[112] L. Appels, J. Baeyens, J. Degrève, and R. Dewil, "Principles and potential of the anaerobic digestion of waste-activated sludge," Progress in Energy and Combustion Science, vol. 34, no. 6, pp. 755-781, 2008.

[113] O. P. Karthikeyan and C. Visvanathan, "Bio-energy recovery from high-solid organic substrates by dry anaerobic bioconversion processes: a review," Reviews in Environmental Science and Bio/Technology, vol. 12, no. 3, pp. 257-284, 2013.

[114] J. Guendouz, P. Buffière, J. Cacho, M. Carrère, and J.-P. Delgenes, "Dry anaerobic digestion in batch mode: design and operation of a laboratory-scale, completely mixed reactor," Waste Management, vol. 30, no. 10, pp. 1768-1771, 2010.

[115] L. Yang, F. Xu, X. Ge, and Y. Li, "Challenges and strategies for solid-state anaerobic digestion of lignocellulosic biomass," Renewable and Sustainable Energy Reviews, vol. 44, pp. 824-834, 2015.

[116] A. Abbassi-Guendouz, E. Trably, J. Hamelin et al., "Microbial community signature of high-solid content methanogenic ecosystems," Bioresource Technology, vol. 133, pp. 256-262, 2013.

[117] J. Lindmark, E. Thorin, R. Bel Fdhila, and E. Dahlquis, "Problems and possibilities with the implementation of simulation and modeling at a biogas plant," in Proceedings of the International Conference on Applied Energy (ICAE '12), Suzhou, China, July 2012.

[118] I. Angelidaki, L. Ellegaard, and B. K. Ahring, "A mathematical model for dynamic simulation of anaerobic digestion of complex substrates: focusing on ammonia inhibition," Biotechnology and Bioengineering, vol. 42, no. 2, pp. 159-166, 1993.

[119] S. Kalyuzhnyi, A. Veeken, and B. Hamelers, "Two-particle model of anaerobic solid state fermentation," Water Science and Technology, vol. 41, no. 3, pp. 43-50, 2000.

[120] D. J. Martin, L. G. A. Potts, and V. A. Heslop, "Reaction mechanisms in solid-state anaerobic digestion. I. The reaction front hypothesis," Process Safety and Environmental Protection, vol. 81, no. 3, pp. 171-179, 2003.

[121] D. J. Martin, "A novel mathematical model of solid-state digestion," Biotechnology Letters, vol. 22, no. 1, pp. 91-94, 2000.
[122] V. A. Vavilin, M. Y. Shchelkanov, and S. V. Rytov, "Effect of mass transfer on concentration wave propagation during anaerobic digestion of solid waste," Water Research, vol. 36, no. 9, pp. 24052409,2002

[123] V. A. Vavilin, L. Y. Lokshina, J. P. Y. Jokela, and J. A. Rintala, "Modeling solid waste decomposition," Bioresource Technology, vol. 94, no. 1, pp. 69-81, 2004.

[124] V. A. Vavilin, S. V. Rytov, L. Y. Lokshina, S. G. Pavlostathis, and M. A. Barlaz, "Distributed model of solid waste anaerobic digestion: effects of leachate recirculation and $\mathrm{pH}$ adjustment," Biotechnology and Bioengineering, vol. 81, no. 1, pp. 66-73, 2003.

[125] V. A. Vavilin and I. Angelidaki, "Anaerobic degradation of solid material: importance of initiation centers for methanogenesis, mixing intensity, and 2D distributed model," Biotechnology and Bioengineering, vol. 89, no. 1, pp. 113-122, 2005.

[126] V. A. Vavilin, L. Y. Lokshina, X. Flotats, and I. Angelidaki, "Anaerobic digestion of solid material: multidimensional modeling of continuous-flow reactor with non-uniform influent concentration distributions," Biotechnology and Bioengineering, vol. 97, no. 2, pp. 354-366, 2007.

[127] H. J. Eber, "Simulation of chemical reaction fronts in anaerobic digestion of solid waste," in Proceedings of the Computational Science and Its Applications (ICCSA '03), pp. 503-512, Montreal, Canada, May 2003.

[128] H. J. Eberl, "The role of spatio-temporal effects in anaerobic digestion of solid waste," Nonlinear Analysis: Theory, Methods \& Applications, vol. 63, no. 5-7, pp. e1497-e1505, 2005.

[129] A. Abbassi-Guendouz, D. Brockmann, E. Trably et al., “Total solids content drives high solid anaerobic digestion via mass transfer limitation," Bioresource Technology, vol. 111, pp. 55-61, 2012.

[130] J. Bollon, R. Le-Hyaric, H. Benbelkacem, and P. Buffiere, "Development of a kinetic model for anaerobic dry digestion processes: focus on acetate degradation and moisture content," Biochemical Engineering Journal, vol. 56, no. 3, pp. 212-218, 2011.

[131] F. Liotta, P. Chatellier, G. Esposito et al., "Modified Anaerobic Digestion Model No.1 for dry and semi-dry anaerobic digestion of solid organic waste," Environmental Technology, vol. 36, no. 5-8, pp. 870-880, 2015.

[132] F. Xu, Z.-W. Wang, L. Tang, and Y. Li, "A mass diffusion-based interpretation of the effect of total solids content on solidstate anaerobic digestion of cellulosic biomass," Bioresource Technology, vol. 167, pp. 178-185, 2014.

[133] S. Pommier, D. Chenu, M. Quintard, and X. Lefebvre, "A logistic model for the prediction of the influence of water on the solid waste methanization in landfills," Biotechnology and Bioengineering, vol. 97, no. 3, pp. 473-482, 2007.

[134] L. A. Fdez-Güelfo, C. Álvarez-Gallego, D. Sales, and L. I. Romero García, "Dry-thermophilic anaerobic digestion of organic fraction of municipal solid waste: methane production modeling," Waste Management, vol. 32, no. 3, pp. 382-388, 2012.

[135] J. Fernández, M. Pérez, and L. I. Romero, "Kinetics of mesophilic anaerobic digestion of the organic fraction of municipal solid waste: influence of initial total solid concentration," Bioresource Technology, vol. 101, no. 16, pp. 6322-6328, 2010.

[136] L. N. Liew, J. Shi, and Y. Li, "Methane production from solidstate anaerobic digestion of lignocellulosic biomass," Biomass and Bioenergy, vol. 46, pp. 125-132, 2012.

[137] D. Brown, J. Shi, and Y. Li, "Comparison of solid-state to liquid anaerobic digestion of lignocellulosic feedstocks for biogas production," Bioresource Technology, vol. 124, pp. 379-386, 2012. 
[138] X. Tong, L. H. Smith, and P. L. McCarty, "Methane fermentation of selected lignocellulosic materials," Biomass, vol. 21, no. 4, pp. 239-255, 1990.

[139] J.-C. Motte, R. Escudié, N. Bernet, J.-P. Delgenes, J.-P. Steyer, and C. Dumas, "Dynamic effect of total solid content, low substrate/inoculum ratio and particle size on solid-state anaerobic digestion," Bioresource Technology, vol. 144, pp. 141-148, 2013.

[140] F. Xu, Z.-W. Wang, and Y. Li, "Predicting the methane yield of lignocellulosic biomass in mesophilic solid-state anaerobic digestion based on feedstock characteristics and process parameters," Bioresource Technology, vol. 173, pp. 168-176, 2014.

[141] F. Xu, Y. Li, and Z.-W. Wang, "Mathematical modeling of solidstate anaerobic digestion," Progress in Energy and Combustion Science, vol. 51, pp. 49-66, 2015.

[142] L. Li, Q. He, Y. Ma, X. Wang, and X. Peng, "Dynamics of microbial community in a mesophilic anaerobic digester treating food waste: relationship between community structure and process stability," Bioresource Technology, vol. 189, pp. 113120, 2015.

[143] J. W. Lim, C.-L. Chen, I. J. R. Ho, and J.-Y. Wang, "Study of microbial community and biodegradation efficiency for singleand two-phase anaerobic co-digestion of brown water and food waste," Bioresource Technology, vol. 147, pp. 193-201, 2013.

[144] S.-K. Cho, W.-T. Im, D.-H. Kim, M.-H. Kim, H.-S. Shin, and S.E. Oh, "Dry anaerobic digestion of food waste under mesophilic conditions: performance and methanogenic community analysis," Bioresource Technology, vol. 131, pp. 210-217, 2013.

[145] S. Wan, L. Sun, J. Sun, and W. Luo, "Biogas production and microbial community change during the Co-digestion of food waste with chinese silver grass in a single-stage anaerobic reactor," Biotechnology and Bioprocess Engineering, vol. 18, no. 5, pp. 1022-1030, 2013.

[146] L. Li, Q. He, Y. Ma, X. Wang, and X. Peng, "A mesophilic anaerobic digester for treating food waste: process stability and microbial community analysis using pyrosequencing," Microbial Cell Factories, vol. 15, no. 1, article no. 65, 2016.

[147] M. Zamanzadeh, L. H. Hagen, K. Svensson, R. Linjordet, and S. J. Horn, "Anaerobic digestion of food waste-effect of recirculation and temperature on performance and microbiology," Water Research, vol. 96, pp. 246-254, 2016.

[148] M. Gulhane, P. Pandit, A. Khardenavis, and D. Singh, "Study of microbial community plasticity for anaerobic digestion of vegetable waste in Anaerobic Baffled Reactor," Renewable Energy, vol. 96, pp. 246-254, 2016.

[149] X. Guo, C. Wang, F. Sun, W. Zhu, and W. Wu, "A comparison of microbial characteristics between the thermophilic and mesophilic anaerobic digesters exposed to elevated food waste loadings," Bioresource Technology, vol. 152, pp. 420-428, 2014.

[150] F. Ali Shah, Q. Mahmood, M. Maroof Shah, A. Pervez, and S. Ahmad Asad, "Microbial ecology of anaerobic digesters: the key players of anaerobiosis," The Scientific World Journal, vol. 2014, Article ID 183752, 21 pages, 2014.

[151] H. Bouallagui, M. Torrijos, J. J. Godon et al., "Microbial monitoring by molecular tools of a two-phase anaerobic bioreactor treating fruit and vegetable wastes," Biotechnology Letters, vol. 26, no. 10, pp. 857-862, 2004.

[152] L. Manoharan, S. K. Kushwaha, K. Hedlund, and D. Ahrén, "Captured metagenomics: large-scale targeting of genes based on 'sequence capture' reveals functional diversity in soils," DNA Research, vol. 22, no. 6, pp. 451-460, 2015.

[153] H. Sanguin, B. Remenant, A. Dechesne et al., "Potential of a $16 \mathrm{~S}$ rRNA-based taxonomic microarray for analyzing the rhizosphere effects of maize on Agrobacteriumspp. and bacterial communities," Applied and Environmental Microbiology, vol. 72, no. 6, pp. 4302-4312, 2006.

[154] H. Sanguin, A. Herrera, C. Oger-Desfeux et al., "Development and validation of a prototype $16 \mathrm{~S}$ rRNA-based taxonomic microarray for Alphaproteobacteria," Environmental Microbiology, vol. 8, no. 2, pp. 289-307, 2006.

[155] M. Kyselková, J. Kopecký, T. Felföldi et al., "Development of a 16S rRNA gene-based prototype microarray for the detection of selected actinomycetes genera," International Journal of General and Molecular Microbiology, vol. 94, no. 3, pp. 439-453, 2008.

[156] W.-T. Liu, A. D. Mirzabekov, and D. A. Stahl, "Optimization of an oligonucleotide microchip for microbial identification studies: a non-equilibrium dissociation approach," Environmental Microbiology, vol. 3, no. 10, pp. 619-629, 2001.

[157] S. Schönmann, A. Loy, C. Wimmersberger et al., "16S rRNA gene-based phylogenetic microarray for simultaneous identification of members of the genus Burkholderia," Environmental Microbiology, vol. 11, no. 4, pp. 779-800, 2009.

[158] A. E. Warsen, M. J. Krug, S. LaFrentz, D. R. Stanek, F. J. Loge, and D. R. Call, "Simultaneous discrimination between 15 fish pathogens by using 16 S ribosomal DNA PCR and DNA microarrays," Applied and Environmental Microbiology, vol. 70, no. 7, pp. 4216-4221, 2004.

[159] I. H. Franke-Whittle, S. H. Klammer, and H. Insam, "Design and application of an oligonucleotide microarray for the investigation of compost microbial communities," Journal of Microbiological Methods, vol. 62, no. 1, pp. 37-56, 2005.

[160] J. Peplies, C. Lachmund, F. O. Glöckner, and W. Manz, "A DNA microarray platform based on direct detection of rRNA for characterization of freshwater sediment-related prokaryotic communities," Applied and Environmental Microbiology, vol. 72, no. 7, pp. 4829-4838, 2006.

[161] S. Demanèche, H. Sanguin, J. Poté et al., "Antibiotic-resistant soil bacteria in transgenic plant fields," Proceedings of the National Academy of Sciences of the United States of America, vol. 105, no. 10, pp. 3957-3962, 2008.

[162] A. Loy, A. Lehner, N. Lee et al., "Oligonucleotide microarray for 16S rRNA gene-based detection of all recognized lineages of sulfate-reducing prokaryotes in the environment," Applied and Environmental Microbiology, vol. 68, no. 10, pp. 5064-5081, 2002.

[163] S. Siripong, J. J. Kelly, D. A. Stahl, and B. E. Rittmann, "Impact of prehybridization PCR amplification on microarray detection of nitrifying bacteria in wastewater treatment plant samples," Environmental Microbiology, vol. 8, no. 9, pp. 1564-1574, 2006.

[164] S. K. Kushwaha, L. Manoharan, T. Meerupati, K. Hedlund, and D. Ahren, "Erratum to: MetCap: a bioinformatics probe design pipeline for large-scale targeted metagenomics," $B M C$ Bioinformatics, vol. 17, article 39, 2016.

[165] https://www.illumina.com/technology/next-generation-sequencing/sequencing-technology.html.

[166] https://www.thermofisher.com/in/en/home/life-science/sequencing/next-generation-sequencing/ion-torrent-next-generationsequencing-workflow/ion-torrent-next-generation-sequencingrun-sequence/ion-proton-system-for-next-generation-sequencing.html.

[167] http://www.pacb.com/products-and-services/pacbio-systems/ rsii/.

[168] F. J. Azuaje, M. Heymann, A.-M. Ternes et al., "Bioinformatics as a driver, not a passenger, of translational biomedical research: 
perspectives from the 6th Benelux bioinformatics conference," Journal of Clinical Bioinformatics, vol. 2, no. 1, article no. 7, 2012.

[169] P. Hugenholtz, "Exploring prokaryotic diversity in the genomic era," Genome Biology, vol. 3, no. 2, pp. 0003.1-0003.8, 2002.

[170] T. Thomas, J. Gilbert, and F. Meyer, "Metagenomics-a guide from sampling to data analysis," Microbial Informatics and Experimentation, vol. 2, no. 1, 2012.

[171] J. A. Gilbert, F. Meyer, D. Antonopoulos et al., "Meeting report: the terabase metagenomics workshop and the vision of an earth microbiome project," Standards in Genomic Sciences, vol. 3, no. 3, pp. 243-248, 2010.

[172] T. O. Delmont, C. Malandain, E. Prestat et al., "Metagenomic mining for microbiologists," ISME Journal, vol. 5, no. 12, pp. 1837-1843, 2011.

[173] J. A. Gilbert, F. Meyer, and M. J. Bailey, "The Future of microbial metagenomics (or is ignorance bliss)," The ISME Journal, vol. 5, no. 5, pp. 777-779, 2011. 

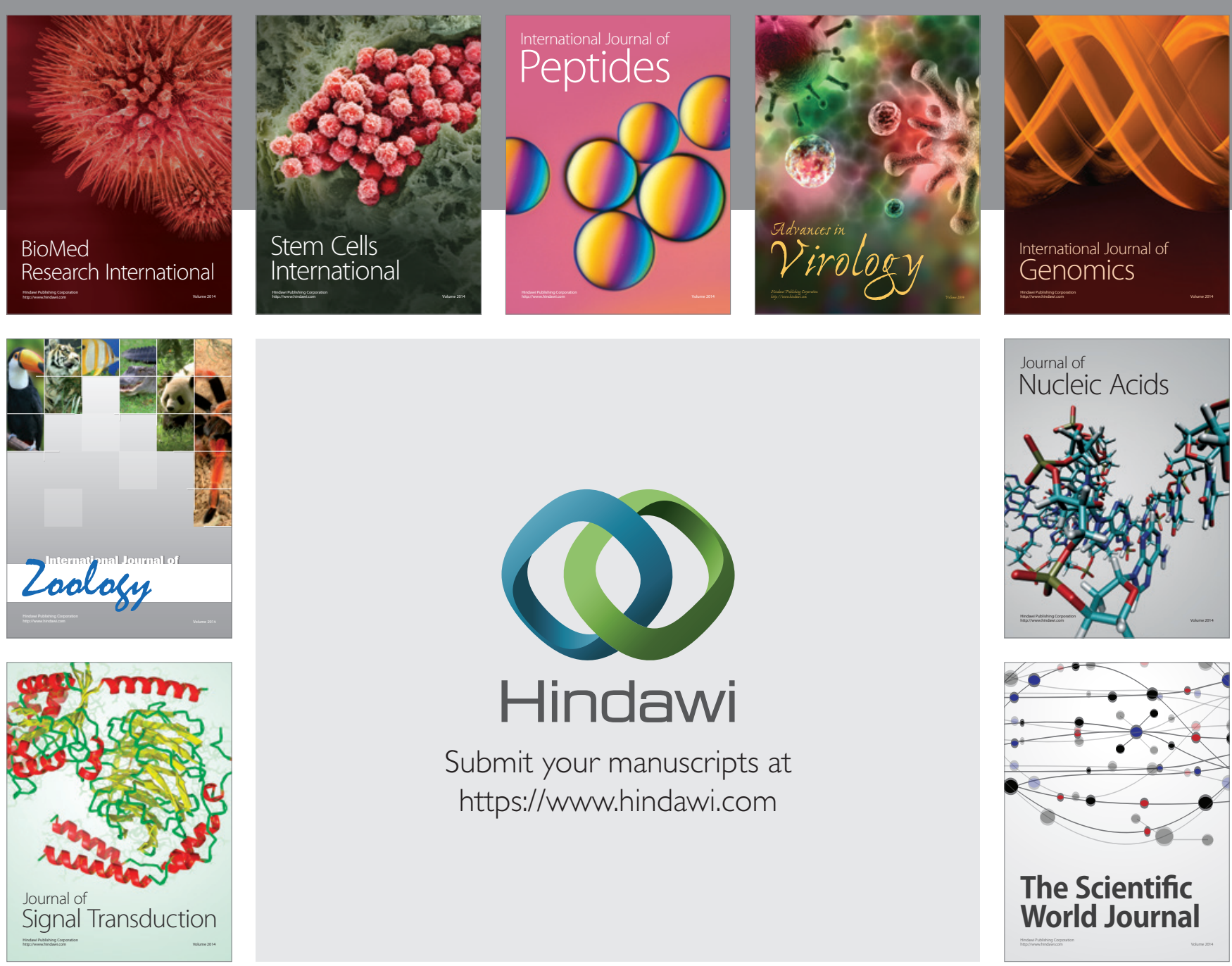

Submit your manuscripts at

https://www.hindawi.com
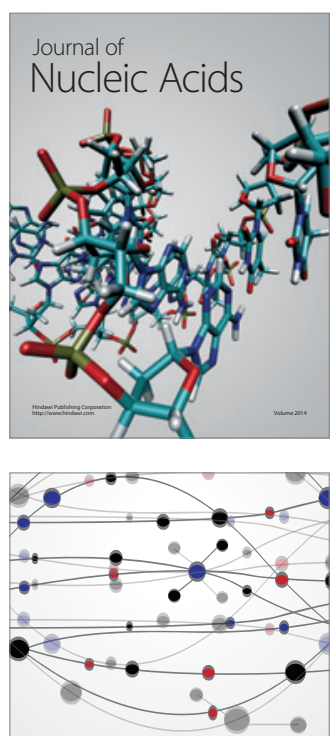

The Scientific World Journal
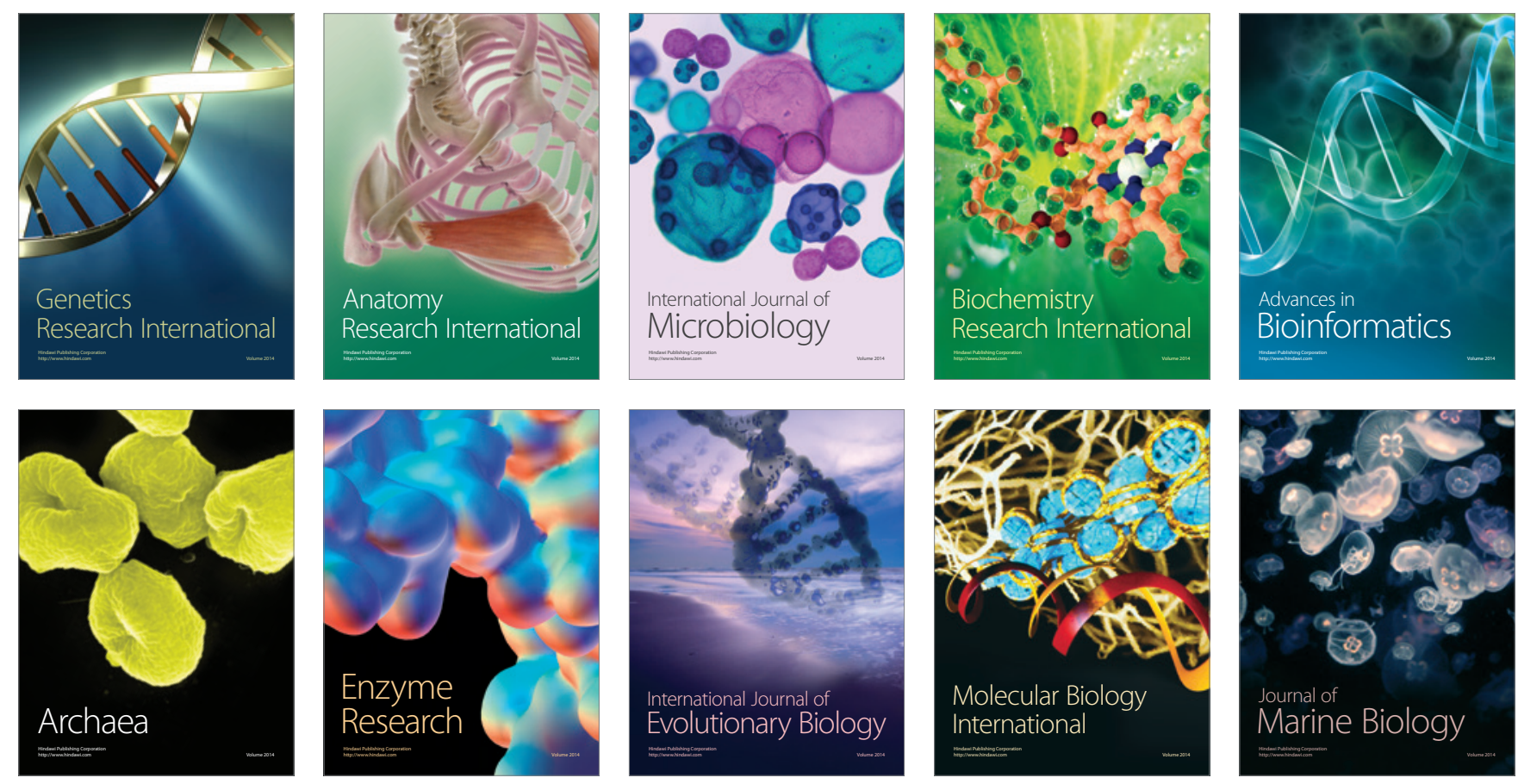